\title{
ANNUITIZATION: KEEPING YOUR OPTIONS OPEN
}

\author{
Irena Dushi* \\ Anthony Webb \\ CRR WP 2004-04 \\ Released: March 2004 \\ Draft Submitted: February 2004 \\ Center for Retirement Research at Boston College \\ 550 Fulton Hall \\ 140 Commonwealth Ave. \\ Chestnut Hill, MA 02467 \\ Tel: 617-552-1762 Fax: 617-552-1750 \\ http://www.bc.edu/crr
}

* Irena Dushi is a research analyst at the International Longevity Center. Anthony Webb is a senior research analyst at the International Longevity Center. The research reported herein was performed pursuant to a grant from the U.S. Social Security Administration (SSA) to the Center for Retirement Research at Boston College (CRR). This grant was awarded through the CRR's Steven H. Sandell Grant Program for Junior Scholars in Retirement Research. The opinions and conclusions are solely those of the authors and should not be construed as representing the opinions or policy of the SSA or any agency of the Federal Government or of the CRR. We would like to thank John Ameriks, Jeffrey Brown, Marjorie Flavin, Leora Friedberg, Kathleen McGarry, Sara Rix, participants at the Society of Actuaries 2002 Annual Meeting and colleagues at the International Longevity Center for very helpful comments. We are grateful to Ben Tarlow and Gregor Franz for research assistance.

(C) 2004, by Irena Dushi and Anthony Webb. All rights reserved. Short sections of text, not to exceed two paragraphs, may be quoted without explicit permission provided that full credit, including (@) notice, is given to the source. 


\title{
About the Sandell Grant Program
}

This paper received funding from the Steven H. Sandell Grant Program for Junior Scholars in Retirement Research. Established in 1999, the Sandell program's purpose was to promote research on retirement issues by junior scholars in a wide variety of disciplines, including actuarial science, demography, economics, finance, gerontology, political science, psychology, public administration, public policy, sociology, social work, and statistics. The program was funded through a grant from the Social Security Administration (SSA). Each grant awarded was up to $\$ 25,000$. In addition to submitting a paper, successful applicants also present their results to SSA in Washington, DC.

\section{About the Center for Retirement Research}

The Center for Retirement Research at Boston College, part of a consortium that includes a parallel centers at the University of Michigan and the National Bureau of Economic Research, was established in 1998 through a grant from the Social Security Administration. The goals of the Center are to promote research on retirement issues, to transmit new findings to the policy community and the public, to help train new scholars, and to broaden access to valuable data sources. Through these initiatives, the Center hopes to forge a strong link between the academic and policy communities around an issue of critical importance to the nation's future.

\author{
Center for Retirement Research at Boston College \\ 550 Fulton Hall \\ 140 Commonwealth Ave. \\ Chestnut Hill, MA 02467 \\ phone: 617-552-1762 fax: 617-552-1750 \\ e-mail: crr@bc.edu \\ http://www.bc.edu/crr
}

Affiliated Institutions:

American Enterprise Institute

The Brookings Institution

Massachusetts Institute of Technology

Syracuse University

Urban Institute 


\begin{abstract}
Annuities provide insurance against outliving one's wealth. Previous studies have indicated that, for many households, the value of the longevity insurance should outweigh the actuarial unfairness of prices in the voluntary annuity market. Nonetheless, voluntary annuitization rates are extremely low.

Previous research on the value of annuitization has compared the alternative of an optimal decumulation of unannuitized wealth with the alternative of annuitizing al unannuitized wealth at age 65. We relax these assumptions, allowing households to annuitize any part of their unannuitized wealth at any age and to return to the annuity market as many times as they wish.

Using numerical optimization techniques, and retaining the assumption made in previous research that half of the household wealth is pre-annuitized, we conclude that it is optimal for couples to delay annuitization until they are aged 74 to 89 , and in some cases never to annuitize. It is usually optimal for single men and women to annuitize at substantially younger ages, around 65 and 70 respectively. Households that annuitize will generally wish to annuitize only part of their unannuitized wealth.

Using data from the Asset and Health Dynamics Among the Oldest Old and Health and Retirement Study panels, we show that much of the failure of the average currently retired household to annuitize can be attributed to the exceptionally high proportion of the wealth of these cohorts that is pre-annuitized. We expect younger cohorts to have smaller proportions of pre-annuitized wealth and we project increasing demand for annuitization as successive cohorts age.
\end{abstract}

JEL Codes: D91, E21, G11, J14, J26 
Annuities provide insurance against outliving one's wealth. Previous research by Mitchell et al (1999) has suggested that although annuities are actuarially unfair, load factors alone cannot explain the almost total absence of voluntary annuitization among single individuals. Brown and Poterba (2000) find that longevity risk pooling reduces the value of annuitization to married couples, but not to levels that would, for plausible parameter values, explain the almost total lack of voluntary annuitization.

The above authors compare the alternative of an optimal decumulation of unannuitized wealth with that of annuitizing all unannuitized wealth at age 65. In practice, households can annuitize at any age, can annuitize any proportion of their unannuitized wealth, and can return to the annuity market as many times as they wish. If there are advantages to delay or if the marginal value of further annuitization decreases with increases in the proportion of wealth that is pre-annuitized, then the value of annuitizing at least some wealth at the optimal age will be even greater. The almost total absence of voluntary annuitization is thus even more puzzling than it first appears.

We therefore extend the above authors' work by allowing households to annuitize any proportions of their unannuitized wealth at any ages. We examine whether there are age-related variations in the degree of actuarial unfairness as these might affect the optimal age at which to annuitize. We provide evidence that the degree of actuarial unfairness does not, in fact, vary significantly with age. We also find that small agerelated variations in the degree of actuarial unfairness would not significantly affect the optimal age.

Assuming the same proportions of pre-annuitized wealth and degrees of risk aversion as those used in previous research, we find that it is usually optimal for married couples to delay annuitization for substantial periods. However, it is usually optimal for single individuals to annuitize soon after age 65. Even when a household does annuitize, it will usually choose to annuitize only part of its unannuitized wealth. An increase in the degree of actuarial unfairness has the effect of inducing a delay in annuitization and a reduction in the amount annuitized. Highly risk-averse households will find it optimal to annuitize larger proportions of their wealth and at younger ages. To illustrate, assuming a 
typical annuity expected present value of 85.6 percent, a married couple with none of its wealth pre-annuitized will wish to annuitize at age 77 when its coefficient of risk aversion is two and at 70 when its coefficient of risk aversion is five. The expected present value of an annuity is calculated by dividing the stream of payments, discounted by survival probabilities and a rate of interest, by the purchase price.

When half the household's wealth is pre-annuitized, the couple will never annuitize when their coefficient of risk-aversion is two, but will annuitize at 73 when the coefficient equals five. Of course, when offered an actuarially fair annuity, all household types immediately annuitize all of their unannuitized wealth provided the survivor benefit is appropriate and they are not unduly impatient. In contrast to married couples, single men and women will usually wish to annuitize either at age 65 , the starting point of our calculations, or very soon thereafter.

When we assume that households have mortality equal to that of the average annuitant, it becomes optimal for households to annuitize at younger ages, at smaller degrees of risk aversion and to annuitize larger proportions of their unannuitized wealth.

Although the above analysis provides an explanation of why married couples do not annuitize on retirement, it does not explain why few households appear to annuitize at any age. Previous authors either disregarded pre-annuitized wealth, or assumed that one half of the household's wealth was pre-annuitized through employer pensions and Social Security. Using data from waves 2-5 of the Health and Retirement Study, a panel of individuals aged 51-61 in 1992 and their spouses of any age, we calculated the balance sheets of households as they turned 65. We found that the proportion of pre-annuitized wealth was generally much larger. Annuitized defined benefit pension and Social Security wealth comprised more than half of total financial wealth for 94 percent of households. We sorted households by total wealth and calculated the mean proportion of pre-annuitized wealth for the median 20 percent of married couples. Pre-annuitized wealth equaled 94 percent of the total for those that had no pension, 86 percent for those with a defined benefit (DB) plan, and 75 percent for those with only a defined contribution (DC) plan. Our simulations indicate that, given plausible assumptions regarding actuarial unfairness and levels of risk-aversion, these married couples are too highly annuitized to annuitize voluntarily at any age, regardless of pension type. We find 
that single women are even more highly annuitized, but that, lacking longevity risk pooling, it can sometimes be optimal for them to annuitize depending on their degree of risk aversion. If it is optimal for a single woman to annuitize, the most appropriate age is either at age 65 or soon thereafter. There were too few single men to produce meaningful results, but their optimal plans would resemble those of single women with similar proportions of pre-annuitized wealth.

Thus, as far as the median household is concerned, if there is an "annuity puzzle", it would appear to be restricted to single individuals. Wealthier households typically have smaller proportions of pre-annuitized wealth. For plausible utility functions and assuming that their greater wealth is not a reflection of a stronger bequest motive, they will value annuitization more highly. There is also a strong and well documented relationship between wealth and longevity. ${ }^{1}$ If wealthier households believe that they have lower than average mortality, this will further increase the value they place on annuitization. It is not unreasonable to assume that the median household believes it has population average mortality. However, calculating optimal plans for wealthier households involves constructing wealth related subjective mortality tables, and is a subject that we defer to future research.

Although currently retired households are highly annuitized, subsequent birth cohorts will have much smaller proportions of pre-annuitized wealth as DC pensions, which almost never mandate annuitization, displace DB plans. The increase in the Social Security normal retirement age will reduce the real value of Social Security wealth. Poterba, Venti, and Wise (2000) project that, as a result, the mean 401(k) plan balance of the cohort retiring in 2025 will exceed their mean Social Security wealth, even allowing for the impact of increased longevity on the latter. The reforms proposed by the President's Commission (2001), if enacted without a provision for mandatory annuitization, will further reduce the compulsorily annuitized proportion of a household's wealth. Munnell (2003) highlights the impact of projected increases in Medicare part B premiums and in the proportion of retirees who will pay income tax on Social Security.

\footnotetext{
${ }^{1}$ We refer the reader to Attanasio and Hoynes (2000), Hurd, McFadden and Merrill (1999), and Menchik (1993). With the exception of Menchik, whose data is old, these papers suffer from the disadvantage for our purposes of conditioning mortality on current, rather than initial wealth. Current wealth is unlikely to be exogenous, and calculations based on the data in these papers would be affected by survivor bias.
} 
She calculates that average Social Security income replacement rates could drop from the current 41.2 percent to 26.9 percent by 2030 .

We simulate the impact of changes in pension structure by replacing DB pension wealth by DC wealth of equivalent present value. Annuitization becomes more attractive to both married couples and single women, but couples will only annuitize when the annuity expected present value and coefficient of risk aversion are both at the top of our assumed range. Even then, they will delay until age 78 .

The remainder of the paper is organized as follows. The first section discusses trends in pension provision and in the amount and composition of household wealth. The second summarizes the findings of previous research. The third describes the results of our simulations. Section four offers explanations for the lack of demand for annuities among the currently old and forecasts demand among the HRS and subsequent birth cohorts as they age. Section five concludes.

\section{Section I. Trends in Pension Provision and Household Wealth}

\section{Pension Provision}

The past twenty years has seen a major shift in employer pension provision away from annuitized defined benefit pension plans towards $401(\mathrm{k})$ and other defined contribution plans. Friedberg and Webb (2003) report that among employees with a pension plan in 1983, 87 percent had a DB plan and 40 percent a DC plan. By 1998, 44 percent had a DB plan and 79 percent a DC plan. However, DB pensions still predominate among workers nearing retirement. Among pensioned employees in the HRS in 1992 and then aged 51-61, 80 percent had a DB plan and 40 percent a DC plan. ${ }^{2}$

Defined benefit pension plans typically pay benefits in annuitized form, although Brown and Warshawsky (2001) report an increase from 14 to 22 percent over the period 1991-1997 in the proportion of DB plans offering a 100 percent lump sum option. By comparison, Brown, Mitchell, Poterba, and Warshawsky (2001) find that annuity payments are available to only 17 percent of private sector defined contribution pension

\footnotetext{
${ }^{2}$ As of wave 5, the latest wave for which data is available, this cohort is aged 59-69 and entering retirement.
} 
participants. Furthermore, the Investment Company Institute (2000) reports that annuitization is almost never compulsory in such plans. ${ }^{3}$ It follows that the displacement of DB by DC plans will lead to a considerable fall in coming years in the proportion of employer pension wealth that is compulsorily annuitized.

A simple calculation of the increase in the proportion of pension plans that offer a lump sum option considerably understates the trend toward voluntary annuitization. As the 401(k) system matures, the average duration of participation and therefore the average plan balance will increase. Using employee reported data, we calculate mean 401(k) wealth to be $\$ 78,360$ in 1992 dollars among HRS households aged 65 who reported ever having participated and who had not closed their account. The distribution of plan balances is highly skewed, and the corresponding median plan balance is only $\$ 26,353$. As only 19 percent of HRS households reported having accounts, the mean balance over all households is only $\$ 14,744$. In contrast, Poterba, Venti and Wise (2002) project mean balances averaged over all households of $\$ 103,000$ and $\$ 136,500$ respectively for the cohorts retiring in 2025 and $2035 .^{4}$

\section{Household Wealth}

Using data from waves 2-5, we show in Tables 1a -1e, the financial position at the first interview after age 65 , of those HRS households that had turned 65 by 2000 . At that interview 46 percent of married men and 39 percent of single women in the panel had attained age 65 , and of these, 48 percent of married men and 44 percent of single women had retired. ${ }^{5}$

\footnotetext{
${ }^{3}$ Individuals may withdraw funds from their pension plan and buy a non-qualifying annuity. This is less tax-efficient than purchasing a qualified annuity within the DC plan or rolling the funds over into an IRA and then purchasing a qualifying annuity within the IRA. Qualified annuity payments and non-annuitized withdrawals from pension plans are both taxed as income, but tax regulations require that the recipient of the non-qualified annuity also pay tax on the part of the annuity that is deemed not to represent a return of capital; the so-called "inclusion ratio". Differences between the taxation of the insurance company's qualifying and non-qualifying life funds may also affect the annuity rates offered. Men may find it advantageous to take an IRA annuity rather than one offered by the pension plan because pension plans, including $401(\mathrm{k}) \mathrm{s}$, are legally required to offer unisex annuity rates.

${ }^{4}$ Their Table II in 1992 dollars and assuming a 50:50 bond/stock portfolio.

${ }^{5}$ An individual is considered to be retired if he reported that he/she was "completely retired" and that he was not doing any work for pay.
} 
Gustman and Steinmeier (1999) have documented substantial discrepancies between employer and employee reported pension data. It is possible that the accuracy of the employee reported data has improved as people enter retirement and become better aware of their entitlements. On the other hand, the accuracy of the employer provided data, which was collected once only, in 1992, may well have declined as it was applied to each succeeding wave. We have therefore chosen to calculate pension wealth from selfreported pension and Social Security data. We assume all households have population average mortality. Excluding Supplementary Security Income (SSI) produces very low levels of annuitized wealth in the bottom wealth decile. We include SSI in Social Security wealth, assuming that SSI benefits will continue in payment for the remainder of the individuals' lives.

We rank households by total wealth and calculate the mean of each wealth component for each decile. There are significant differences in the amount and composition of total wealth between married couples, single men and single women. We therefore report separate results at Tables $1 \mathrm{a}$ and $1 \mathrm{~b}$ for married couples and single women, there being insufficient single men in the sample to permit an analysis by wealth decile. $^{6}$ Table $1 \mathrm{c}$ reports overall means. Tables $1 \mathrm{~d}$ and $1 \mathrm{e}$ report means for the median 20 percent by household and pension type.

Married couples are much wealthier than single individuals, with the difference being greatest in unannuitized financial wealth and least in Social Security wealth. In the top decile, the non-pension financial retirement wealth of single women is only a third of that of couples. Among both couples and single women, housing and Social Security wealth is much more equally distributed than employer pension wealth, with non-pension wealth being highly concentrated among the wealthiest households.

Among couples, mean Social Security wealth varies from \$210,237 in the bottom decile to $\$ 403,614$ in the top one. Mean DB and DC employer pension wealth ranges from $\$ 8,020$ in the bottom decile to $\$ 494,085$ in the top. The overwhelming majority of employer pension wealth is held in DB plans. DC plan balances average 10 percent of pension wealth in the bottom nine deciles rising to 26 percent in the top decile. As a

\footnotetext{
${ }^{6}$ There were 188 single men of which 67 had a DB pension, 5 a DC and 116 had no pension.
} 
result, mean annuitized wealth exceeds 85 percent of financial wealth among couples in all the first six deciles and is still 53 percent in the top decile.

Single women are even more highly annuitized than married couples, with mean annuitized wealth exceeding 91 percent of total financial wealth in the first six deciles and equaling 62 percent in the top decile. Only 6 percent of single women have less than half their financial wealth in annuitized form, and only 21 percent have less than three quarters. A majority of single women has almost no annuitizable financial wealth and only 30 percent have more than $\$ 50,000$.

We compare our results with Gustman, Mitchell, Samwick, and Steinmeier (1997) analysis of wave 1 of the HRS when the panel was aged 51-61. We obtain somewhat higher proportions of pre-annuitized wealth, primarily Social Security. This is to be expected, as Gustman et al pro-rated pension and Social Security accruals to individuals' ages in 1992, whereas we calculate pension and Social Security wealth at age 65. To check the validity of our figures, we compared the average Social Security benefit reported by the HRS sample with the average benefits reported by the Social Security Administration.

Mitchell and Moore (1997) further analyze Gustman et al and show that it is only above the $95^{\text {th }}$ percentile of total wealth that average non-pension financial wealth exceeds combined pension and Social Security wealth. They do not distinguish between annuitized and unannuitized pension wealth, but as our analyses show, except in the top wealth decile, the average DC plan balance in this cohort is quite modest. Even though, for the reasons explained above, they arrive at lower figures for Social Security wealth, both their and our analyses clearly show that most households entering retirement hold more than half of their financial wealth in annuitized form.

Tables 2a-2e report the same analysis for the Asset and Health Dynamics among the Oldest Old (AHEAD) households in the year 2000. This is a panel born in 1923 or earlier and their spouses of any age. Their distribution of wealth by category and wealth decile is similar to that of the HRS households. Average pension and Social Security wealth is much smaller, mainly reflecting the shorter remaining life expectancy of this cohort. 


\section{Findings of Previous Research}

Yaari (1965) was the first to derive conditions under which full annuitization was optimal. His restrictive assumptions included complete markets, the absence of a bequest motive, and the availability of actuarially fair annuities. Davidoff, Brown and Diamond (2003) relax the assumption of complete markets and find that full annuitization is often no longer optimal.

Most of the literature has analyzed the effect of annuitization on expected utility. An alternative approach, taken by Milevsky (1998, 2000), has been to calculate the impact of deferring annuitization on expected returns, and the probability that deferral will leave the individual no worse off. Assuming that only nominal annuities are available, he investigated a strategy of postponing annuitization and investing in equities. $^{7}$ He assumed that individuals who postponed annuitization would consume from their unannuitized wealth at a rate equal to the annuity income they could have initially obtained. In practice one would expect individuals to re-evaluate their consumption plans in the light of realized investment returns. He found that individuals who postpone annuitization stand a high probability of being eventually able to buy a larger annuity.

Probability based measures provide little guidance as to what risk of failure is acceptable for any given level of risk-aversion and for this reason we favor utility based analyses. In the first of a series of papers, Mitchell et al (1999) used numerical optimization to calculate a utility based measure of the wealth equivalent of an annuity. They defined the wealth equivalent as the expected present value of the annuity at which an individual would be indifferent between annuitizing all his unannuitized assets and continuing to hold those assets in unannuitized form.

\footnotetext{
${ }^{7}$ Investment linked annuities have in fact been available since 1952 when TIAA-CREF launched its CREF equity based immediate and deferred annuities. Initially, CREF immediate annuities could only be purchased with the proceeds of CREF deferred annuities, and in the first year only six immediate annuity contracts were sold, Greenough (1990). The market remains small. The National Association for Variable Annuities (2002) report overall 2001 immediate annuity sales of $\$ 10.2$ billion, of which only $\$ 0.6$ billion were variable. Brown and Poterba (2000) point out that approximately half of immediate annuity sales are for period certain rather than for life contingent annuities. If applied pro -rata, this suggests sales of immediate life contingent variable annuities of $\$ 300$ million a year.
} 
Assuming a real interest rate of 3 percent, an inflation rate of 3.2 percent, a rate of time preference of 1 percent, no bequest motive, no pre-existing annuities, population mortality, and a coefficient of risk aversion equal to one, they calculated the before tax wealth equivalent of a nominal annuity to be 0.659 for a single male. At a coefficient of two, the wealth equivalent fell to 0.619. If half the individual's wealth was held in the form of a pre-existing real annuity, the wealth equivalents increased to 0.730 and 0.695 under the same assumptions. As discussed above, only a very small proportion of single households have half or less of their financial wealth in annuitized form. These results are therefore representative only of the wealthiest households who may also have a stronger than average bequest motive. ${ }^{8}$

In the same paper, they calculated annuity EPVs at ages 55, 65, and 75. At age 65 , these varied from 75.6 to 92.7 percent, depending on whether one discounts the payments at the Treasury or corporate bond yield curve and whether population or annuitant mortality tables are used. A comparison between these EPVs and the reciprocals of the wealth equivalents referred to in the preceding paragraphs would, at first glance, suggest a substantial role for annuities in financing retirement consumption.

We assume in our calculations that the degree of actuarial unfairness of annuities does not vary with age or marital status. Although Finkelstein and Poterba (2000) find evidence that the degree of adverse selection varies with annuity type, a comparison of (Mitchell et al 1999) EPVs suggests that although the differences between ages 55 and 65 are more substantial, the degree of actuarial unfairness does not change significantly between 65 and 75. There is no clear pattern to the changes between ages 65 and 75 and the largest single change is only 2.3 percent. At very young ages, the insurance company's assumptions regarding rates of return will have a proportionately greater effect on the price of the annuity. At these ages, the insurance company's obligations extend well beyond the life of even the longest maturity bond, and differences between the rate of return used by the insurance company to price the annuity and that assumed by Mitchell et al may significantly affect the EPV.

\footnotetext{
${ }^{8}$ Calculation of the pre-annuitized proportion of total wealth would be significantly affected by the inclusion of housing wealth in the denominator and by one's choice of assumptions about how the use of the house entered into the utility function and whether the house was available to finance consumption. We defer consideration of these issues to future research.
} 
As a check, we calculated the annuity that an individual could purchase at each age from 51 to 105 if insurance companies sold actuarially fair annuities, priced using a three percent real return and the basic annuity 2000 period mortality table. ${ }^{9}$ We then calculated the EPVs of the annuities at the same interest rate, using population mortality tables for the appropriate birth cohorts. At age 65, the EPVs for men and women were 86 and 92 percent respectively. By age 80, the male expected present value had decreased to 82 percent, but the female had increased to 96 percent. If insurance companies price annuities in this way, then the actuarial unfairness of female annuities would decrease significantly with age, and that of male annuities would increase marginally. This divergence in age-related trends in actuarial unfairness is surprising, but our finding offers no support for the belief that people with population life expectancy would face significantly greater actuarial unfairness were they to delay annuitization.

An individual who postpones annuitization does however face the risk that insurance companies might reduce annuity rates if long-term interest rates declined. This risk can be largely, if not wholly, hedged by investing in a portfolio of bonds of appropriate duration. What cannot be hedged is the risk that annuity rates might fall as a result of unexpected increases in longevity among the annuitant population.

Brown and Poterba (2000) extended the analysis to married couples considering the purchase of a joint life and survivor annuity. They assumed that couples have a utility function of the following form:

$$
U_{m}\left(C_{t}^{m}, C_{t}^{f}\right)=\frac{\left(C_{t}^{m}+\lambda C_{t}^{f}\right)^{1-\gamma}}{1-\gamma}, U_{f}\left(C_{t}^{f}, C_{t}^{m}\right)=\frac{\left(C_{t}^{f}+\lambda C_{t}^{m}\right)^{1-\gamma}}{1-\gamma}
$$

where ? measures the jointness of consumption, $C_{t}^{m}, C_{t}^{f}$ denote the consumption of the husband and wife at time $t$, and ? is the coefficient of risk aversion. When ? equals one, all consumption is joint. When ? equals zero, none of the household's consumption is joint. They calculated "annuity equivalent wealth", the premium over expected present value at which a household would surrender the right to purchase an actuarially

\footnotetext{
${ }^{9}$ Basic means that it is formed from industry experience without an additional margin for conservatism. A period table predicts the current mortality of people of varying ages, in contrast to a cohort table that predicts the future mortality of people born in a particular year. We use the basic table because we understand that the insurance industry does not use cohort tables to price annuities.
} 
fair annuity. When there are no pre-existing annuities, annuity equivalent wealth is simply the reciprocal of the wealth equivalent. With pre-existing annuities, this simple relationship breaks down.

The effect of marriage on the value of annuitization depends on whether the married couple is allowed to choose an annuity with a survivor benefit appropriate to its degree of risk aversion and the value of ? in its utility function. ${ }^{10}$ When $?=0$, the rate of interest equals the rate of time preferences, and a real annuity is available, the optimal survivor benefit is 0.5 regardless of the degree of risk aversion. ${ }^{11}$ When $?=1$, the optimal survivor benefit increases from 0.5 with $\log$ utility to almost 1 at very high levels of risk aversion. When $?=0.5$ and $?$ equals five it is 0.652 .

Married couples value annuitization less highly than do single individuals, regardless of the degree of risk-aversion, particularity when much of the household's consumption is joint. This is a result of the ability of couples to pool longevity risk. Assuming population mortality, no pre-existing annuities, a coefficient of risk aversion of two, a rate of time preference and a real rate of interest both of 3 percent, and a rate of inflation of 3.2 percent, Brown and Poterba calculate that annuity equivalent wealth for a 65 year old single man to be 1.576 . When ? equals zero, they calculate the annuity equivalent wealth of a joint life and 50 percent survivor annuity to be 1.244 under the same assumptions. Marriage decreases the value of annuitization by 58 percent. When the coefficient of risk aversion equals ten, their comparable figures are 1.703, 1.407 and 42 percent. At higher values of ? annuitization is even less valuable to married couples, particularly if the annuity has an inappropriate survivor benefit. When ? equals one and the degree of risk aversion equals ten, the optimal survivor benefit is 97 percent. We replicate their calculations and find that the annuity equivalent wealth of a joint life and 50 percent survivor annuity is only 1.108. Annuitization has very little value because a 50 percent survivor annuity gives too little income to the surviving spouse. Even with a

\footnotetext{
${ }^{10}$ If the survivor benefit is inappropriate, or if, in a model with constant inflation, the household is not permitted to purchase an increasing annuity, the value of annuitization also depends on whether fully annuitized households are permitted to save out of their annuity income and to purchase additional annuities with their savings. Brown and Poterba tell us that their households are permitted to save but not to purchase additional annuities.

${ }^{11}$ Brown and Poterba obtain somewhat higher values for annuity equivalent wealth when the survivor ratio is $2 / 3$. This is a result of assuming that the payments from the annuity decline in real terms.
} 
100 percent survivor benefit, we calculate that annuity equivalent wealth is still only 1.278 , significantly less than their value of 1.407 when ? equals zero.

The reciprocals of these results can be compared with the annuity EPVs calculated by Mitchell et al (1999). Using the corporate bond yield curve and population mortality tables, Mitchell et al calculated the expected present value of a joint and survivor annuity at age 65 to be 79.2 percent. Assuming zero complementarity in consumption and no bequest motive, we calculate that is it only optimal for a couple with half its wealth preannuitized to annuitize its remaining wealth when its coefficient of risk-aversion exceeds five. When three quarters of the couple's wealth is pre-annuitized, a coefficient of risk aversion greater than 10 is required. The comparable numbers for people with annuitant mortality are 3 and 6.

It is unclear whether it is more appropriate to use annuitant or population mortality. There is a strong relationship between wealth and mortality, and many people with potential annuitizable wealth may not only have lower than average mortality, but also be aware of that fact. We defer further consideration of this issues to future research.

In practice, households can invest their unannuitized wealth in a variety of asset classes, and insurance companies offer not only nominal annuities but also annuities with payments linked to the returns on Treasury Inflation Protected Securities (TIPS) and stock market securities. Brown, Mitchell, and Poterba (2001) used numerical optimization to calculate the wealth equivalents of investment and inflation linked annuities. They found that for plausible degrees of risk aversion, households would generally value an investment linked annuity more highly than a real annuity because the additional returns more than compensated for the volatility of prospective payments.

They also considered the impact of inflation on the value of nominal annuities. The inflation protection offered by a real annuity had only modest value. The wealth equivalent of nominal annuities decreased only slightly when they assumed i.i.d inflation calibrated to 1926-97 data. When they assumed that inflation followed an AR(1) process the wealth equivalent further decreased, but the difference was only substantial at high coefficients of risk aversion or when the individual had no pre-annuitized wealth. 
The above literature compares annuitizing at some arbitrary age with the alternative of never annuitizing. If the household can do better by delaying, the above calculations will understate the value of annuitizing at the optimal age.

Milevsky and Young (2003) used analytical techniques to calculate the optimal age at which to annuitize. They examined the decision faced by individuals, rather than couples and used a Gompertz approximation to mortality tables. In some specifications they permitted partial annuitization of una nnuitized wealth. They assume that actuarial unfairness reduced the returns on nominal and investment linked annuities by 50 and 100 basis points respectively. When only nominal annuities are available but partial annuitization is not permitted, it is optimal for men and women to annuitize at ages 75 and 80 respectively when the coefficient of risk aversion equals two. The availability of investment linked annuities greatly reduces the optimal age. When investment linked annuities are also available, it becomes optimal for men and women to annuitize at 64 and at 71 respectively.

There are relatively few empirical investigations of the determinants of voluntary annuitization. This is, no doubt, partly due to the rarity of its occurrence. Brown (2001) examined the annuitization plans of individuals who participated in defined contribution (DC) plans and whose plans offered an annuitization option, using household level data to calculate annuity equivalent wealth. In contrast with the very low levels of voluntary annuitization observed in the HRS and AHEAD datasets, he found that almost half of these individuals intended to annuitize their DC pension wealth. He also found that those with higher AEWs were more likely to report that they intended to annuitize.

When Brown wrote his paper, the HRS had only released data from the first two waves of the panel, plus preliminary data from the third. Only a few of the individuals in the study had retired. Our analysis of this data indicates that very few individuals had in fact annuitized by wave 5 when they were aged 59-69. Our simulations indicate that although it can sometimes be optimal for single women with population average mortality and proportion of pre-annuitized wealth to annuitize in her late sixties, it will almost invariably be optimal for married couples to delay annuitization until much more advanced ages. It is thus too soon to determine whether the HRS cohort will eventually act in accordance with their stated intentions. 


\section{Numerical simulations of the Annuitization Decision}

We use numerical optimization techniques to calculate the optimal age at which to annuitize. We focus on the intertemporal evolution of the allocation of the household's portfolio between annuitized and unannuitized wealth. In contrast to previous research, we permit households to annuitize at any age, to annuitize any proportion of their wealth, and to return to the annuity market as many times as they wish. We study both married couples and single individuals, and examine how the level of actuarial unfairness, the existence of pre-annuitized wealth, and the household's degree of risk-aversion affect the age at which it annuitizes and the amounts annuitized.

Following the previous literature, we consider households with both population and annuitant mortality. We use the Social Security Administration life tables for the 1930 male and 1933 female birth cohorts to forecast population mortality, and follow the methodology used by Mitchell et al. (1999) to construct cohort annuitant life tables.

In all our models, we follow Brown and Poterba (2000) and assume that the household's utility function takes the form set out in equation (1). The cost of an annuity is as follows:

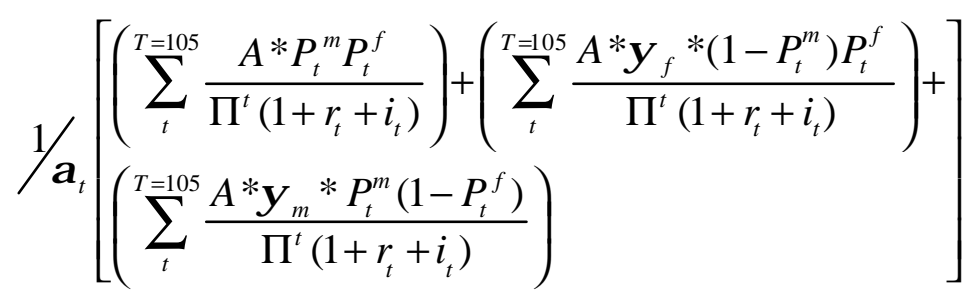

where $A$ is the annual amount payable when both husband and wife are alive, $P_{m}^{t}, P_{f}^{t}$ are the respective probabilities of a man and woman alive at time $t$ surviving to time $t, r_{t}$ and $i_{t}$ are the real interest rate and inflation rate at time $t, \mathrm{a}_{t}$ is the reciprocal of the expected present value of the annuity, and $?_{m}, ?_{f}$ are the husband's and wife's survivor benefits expressed as a decimal of the initial amount payable.

For ease of computation, we assume that couples are only able to purchase annuities with $2 / 3$ percent survivor benefits. LIMRA (1997) reports that insurance companies are willing to offer annuities with almost any survivor benefit. Surviving 
spouses are, of course, only able to buy single life annuities. Pre-annuitized wealth is assumed to be held in a real joint life and 2/3 survivor real annuity. This corresponds with the Social Security annuity provided to a household in which the wife's pension is paid by reason of her husband's contributions. As previously discussed, we also assume that the expected present value of an annuity does not vary with age.

We assume that the inflation rate is zero percent, the rate of time preference is $1 / 1.03$, the real rate of interest is 3 percent, and that the wife is three years younger than the husband, the average for the cohort entering retirement. The insurance market offers not only level but also increasing annuities, and our assumption of zero inflation is therefore equivalent to assuming the purchase of a nominal annuity increasing at a fixed rate of inflation.

We report in Table 3a the ages at which our numerical simulations indicate that households with population life expectancy and varying degrees of risk aversion should start annuitizing their financial wealth. It also shows the proportion of initial financial wealth remaining immediately prior to annuitization. We report results for married couples, single men and single women; for risk aversion coefficients of one, two and five; pre-annuitized proportions of total wealth of zero, 50 and 75 percent; and for annuity EPVs of 85.6 and 79.2 percent. These correspond to the average of Mitchell et al's ages 65 and 75 annuity present values, calculated by reference to the Treasury and corporate bond interest rates respectively. We also report in Table $3 \mathrm{~b}$ corresponding results for households with annuitant mortality. In the simulations with annuitant mortality we assume annuity EPVs of 92.4 and 84.9 percent. These correspond to the averages of the age 65 and age 75 EPVs for individuals with annuitant mortality when one discounts the annuity income at the Treasury strip and corporate bond interest rates, respectively. As a reality check, we also ran simulations assuming no actuarial unfairness, and found that all household types annuitized immediately, even when the annuity provided an inappropriate survivor benefit.

Households of all types are more likely to annuitize and to annuitize at younger ages if they have a large coefficient of risk aversion, a small proportion of pre-annuitized wealth, and are able to annuitize on relatively favorable terms. However, for any given set of parameter values, there are substantial differences between singles and married 
couples in whether, when and how much, they should annuitize. Even when a household annuitizes, it usually annuitizes only a proportion of its wealth. It sometimes returns to the annuity market after a few years to make one or more additional, smaller purchases.

Considering first the households with population life expectancy, in none of the cases examined is it optimal for a married couple to annuitize before age 70. In many cases it is optimal to annuitize in the late 70's and in others it is optimal never to annuitize. Quite small changes in the assumptions can change the optimal age by several years. For example, when no wealth is pre-annuitized, an increase in the degree of risk aversion from one to two decreases the optimal age by six years.

When the coefficient of risk aversion is small or the couple has a large proportion of pre-annuitized wealth, they spend down their unannuitized wealth quite rapidly. This decreases both the proportion of unannuitized wealth and the attractiveness of annuitization. By the time they reach the ages at which the annuitization of even small proportions of wealth would be worthwhile, all their unannuitized wealth has been consumed.

In contrast, single men and women, unable to pool risk within the household, invariably annuitize at age 65 , or soon thereafter, even at low levels of risk aversion, high proportions of pre-annuitized wealth and substantial degrees of actuarial unfairness. It will usually be optimal for surviving spouses to annuitize immediately on the death of their partner.

Figure I shows the optimal paths for consumption, unannuitized and total wealth for a married couple with population mortality and with half its wealth pre-annuitized. We assume that the household's wealth comprises $\$ 280,000$ cash plus a Social Security pension of $\$ 18,000$ a year, reducing to $\$ 12,000$ on the death of either spouse. The expected present discounted value of the pension equals $\$ 280,000$, so half of the household's wealth is pre-annuitized. The household's coefficient of risk aversion is two, the real rate of return and the rate of time preference both equal three percent, the annuity's expected present value is 79.2 percent, and $?=0.5$. The first panel shows the couple's consumption path from age 65 to age 105 for the case in which both spouses survive to that age. The second panel shows the evolution of the household's wealth excluding Social Security. They never annuitize, and both consumption and wealth 
decline until age 90 when they exhaust all their financial wealth. Thereafter, they rely upon Social Security to finance consumption.

Figure II shows the same data for the case in which the coefficient of riskaversion equals five. Consumption declines more slowly prior to annuitization, reflecting the smaller intertemporal elasticity of substitution, and the household first annuitizes at age 82. At that age, 44 percent of the couple's wealth remains unconsumed. They only annuitize 17 percent of their wealth as there are decreasing marginal returns to annuitization. They finally exhaust their unannuitized wealth at age 100 .

We attempted to replicate the calculation by Milevsky and Young (2002) that single men and women with a coefficient of relative risk aversion of 2 and no preannuitized wealth should annuitize at ages 64 and 71, respectively. Their expense load correspond to an expected present value of 91.2 percent, at which level we calculate that both men and women should annuitize at 65 , the age at which we start our simulation. ${ }^{12}$

We suspect that our model predicts earlier annuitization than Milevsky and Young's because their model, while assuming uncertain investment returns, does not permit the individual to save out of his annuity income. Under constant relative riskaversion, the marginal utility of consumption is convex, and uncertainty over future consumption leads households to undertake precautionary saving. We conjecture that their model underestimates the value of annuitization by preventing annuitized households from undertaking desired precautionary saving.

As one might expect, households with annuitant mortality find annuitization more attractive than those with population mortality. They annuitize at lower degrees of risk aversion and higher proportions of pre-annuitized wealth. When they do annuitize, they annuitize a larger proportion of their initial wealth, and make their purchases at younger ages.

Our models incorporate a transaction cost of $\$ 250$. Our analyses of annuity rates suggest that insurance companies face only small fixed costs of producing annuities. ${ }^{13}$ The transaction cost is intended to cover the psychic and time costs of making the

\footnotetext{
${ }^{12}$ We follow their assumption of a 6 percent rate of time preference. We use an expected investment return of 10.12 percent, equal to a weighted average of their risky and risk-free returns.

${ }^{13}$ Consistent with the predictions of models of adverse selection, some U.K. insurers actually charge higher premiums for larger annuities.
} 
annuitization decision. In the absence of this transaction cost, households would optimally choose to annuitize small amounts of their wealth over several years. Changing the amount of the transaction cost has little effect on the age at which annuitization starts or the proportion of wealth that the household annuitizes, but does discourage already highly annuitized households from making small additional purchases. For example, when the coefficient of risk aversion equals two, the household has population mortality, the annuity expected present value is 85.6 percent, and there is no pre-annuitized wealth, doubling the charge leaves the optimal annuitization age unchanged but increases the amount that the household annuitizes by three percent of initial wealth. Halving the charge to $\$ 125$ results in the household annuitizing two years earlier, returning for a second purchase after an interval of four years. The household's annuitized wealth after the second purchase is almost identical to that of the household with the $\$ 250$ transaction charge.

\section{Empirical investigation of the annuitization decision}

We use our numerical optimization program to calculate the optimal annuitization strate gies of the average households in the HRS and AHEAD cohorts. We use coefficients of risk aversion of 1,2 and 5 and EPVs of 85.6 and 79.2 percent, and consider married couples and single women separately.

As we are studying the average household, we assume that they believe they have population average mortality, consistent with rational expectations. Wealthier households will generally have smaller proportions of pre-annuitized wealth and lower mortality, and will therefore value annuitization more highly. As explained previously, we defer consideration of this issue to further research.

We classify households according to whether they are unpensioned, have a DB plan, and in the case of the HRS cohort, whether they only have a DC plan. We calculate the mean annuitized percentage of financial wealth for the median 20 percent of the households in each category. To simulate the effect of the displacement of DB by DC pension wealth, we also calculate the annuitized percentage for DB households in the HRS assuming that DB wealth has been replaced by an equivalent amount of DC wealth. 
Table 4 reports our results. It is never optimal for the married couples in the HRS to annuitize, at either of the assumed expected present values, regardless of pension type or degree of risk aversion. If DB wealth is replaced by an equivalent amount of DC wealth, it can be optimal to annuitize, but only at age 78 , and only if the degrees of risk aversion and actuarial unfairness are at the top and bottom, respectively, of our assumed ranges.

The position of single women is somewhat different. It is usually optimal for single women with DC pensions to annuitize. Single women with DB pensions have larger proportions of pre-annuitized wealth, and those with no pension, still larger proportions. Those with DB pensions may wish to annuitize some of their non-pension wealth if they are risk averse. Those with no pension have almost all of their wealth in the form of Social Security and have too small a proportion of annuitizable financial wealth to make further annuitization worthwhile. Those who annuitize will, however, generally wish to do so soon after retirement. When DB pension wealth is replaced by an equivalent amount of DC wealth, it is optimal for single women to annuitize around age 65 under most plausible assumptions. There are insufficient single men to produce meaningful statistics. Their optimal annuitization strategies would however closely resemble those of single women with similar proportions of pre-annuitized wealth.

We then consider the annuitization decision faced by the AHEAD households. Married couples will only wish to annuitize when they are risk averse, when they have no DB pension, and when they discount the annuity payments at the Treasury bill rate of interest. Those who decide to annuitize will wish to do so immediately. Single women will generally wish to annuitize immediately.

The inconsistency between the HRS and the AHEAD results reflects the fact that our simulations predict that the HRS cohort will have much less financial wealth by the time they reach the ages of the AHEAD cohort than is currently held by the latter cohort. We do not, of course, know what amounts of financial wealth the AHEAD cohort held when they were the current ages of the HRS cohort, but it seems unlikely that their wealth would have exceeded that of the HRS cohort. Their apparent failure of the AHEAD cohort to decumulate to the extent predicted by our simulations may possibly reflect unexpected stock market gains, precautionary saving, or survivor bias. 
Our results show that if there is an "annuity puzzle" among households at median wealth levels, it is primarily among single individuals. These single individuals generally have very modest amounts of annuitizable wealth and it is possible that liquidity considerations play a part in explaining their failure to annuitize.

\section{Conclusions}

Previous research into annuitization has typically assumed that 50 percent of the wealth of households entering retirement is compulsorily annuitized. Our analysis of the HRS shows that this is a very considerable underestimate and that the average percentage of financial wealth that is compulsorily annuitized only falls to 50 percent in the top decile of total wealth. As a result, previous authors have considerably overestimated the value of annuitization to the average household.

The focus of this paper is on the behavior of the median household. Our simulations indicate that, for all pension types, one need look no further than the high proportion of pre-annuitized wealth for the failure of the median currently retired married couple to voluntarily annuitize.

The behavior of single women is more puzzling, as our research suggests that they ought to value annuitization more highly despite their greater proportions of preannuitized wealth. It is possible that liquidity concerns influence their decision. There were insufficient single men in our sample to permit a detailed analysis by pension type, but much of what we say about single women probably also applies to single men.

The displacement of DB by DC pension wealth will lead to a fall in the preannuitized proportion of household wealth that may result in increasing levels of voluntary annuitization among more risk-averse households. Whether it will, in fact, do so, depends on the presence of other impediments to voluntary annuitization such as those considered by Brown and Warshawsky (2001).

Annuitization may well be more attractive to wealthier couples, who have lower average mortality and smaller proportions of pre-annuitized wealth. On the other hand, these households may also have a stronger bequest motive. We defer modeling the behavior of such households to future research. 


\section{Bibliography}

Attanasio, Orazio and Hilary W. Hoynes. 2000. "Differential Mortality and Wealth Accumulation." Journal of Human Resources, Vol 35, no.1:1-29

Brown, Jeffrey R. and James Poterba 2000. "Joint Life Annuities and Annuity Demand by Married Couples.” Journal of Risk and Insurance, 67(4): 527-53.

Brown, Jeffrey R. 2001. "Private Pensions, Mortality Risk, and the Decision to Annuitize." Journal of Public Economics October 2001; 82(1): 29-62

Brown, Jeffrey R., Olivia Mitchell, and James Poterba. 2001. "The Role of Real Annuities and Indexed Bonds in an Individual Accounts Retirement Program." In “Risk Aspects of Investment-Based Social Security Reform” Eds Campbell, J and Feldstein, M University of Chicago Press, Chicago 2001 pp 321-370.

Brown, Jeffrey R and Mark J. Warshawsky, M. 2001. "Longevity Insured Retirement Distributions from Pension Plans: Market and Regulatory Issues.” NBER Working Paper No. 8064.

Brown, Jeffrey R., Olivia Mitchell, James Poterba and Mark J. Warshawsky. 2001. "Taxing Retirement Income: Nonqualified Annuities and Distributions from Qualified Accounts" The Role of Annuity Markets in Financing Retirement, M.I.T. Press, pp.210.

Davidoff, Tomas, Jeffrey R. Brown, and Peter A. Diamond. 2003. “Annuities and Individual Welfare” NBER Working Paper No. 9714

Finkelstein, Amy and James Poterba. 2000. “Adverse Selection in Insurance Markets: Policyholder Evidence from the U.K. Annuity Market" NBER Working Paper No. 8045 .

Friedberg, Leora and Anthony Webb. 2003. "Retirement and the Evolution of Pension Structure,” NBER Working Paper No. 9999.

Gan, Li, Michael D. Hurd, and Daniel McFadden. 2003. “Individual Subjective Survival Curves," NBER Working Paper No. 9480.

Greenough, Wlliam C. 1990. "It's My Retirement Money_-Take Good Care of It: The TIAA-CREF Story” Irwin for Pension Research Council, Wharton School, University of Pennsylvania. 
Gustman, A Mitchell, O Samwick, A and Steinmeier, T 1997 "Pension and Social Security Wealth in the Health and Retirement Study" NBER Working Ppaer No. 5912.

Gustman, Alan L., and Tomas L. Steinmeier.1999. "What People Don't Know About Their Pensions and Social Security: An Analysis Using Linked Data From the Health and Retirement Study” NBER Working Paper No. 7368.

Hurd, M McFadden, D and Merrill, A (2001) "Predictors of Mortality Among The Elderly" Wise,-David-A., ed. Themes in the economics of aging. NBER Conference Report series. Chicago and London: University of Chicago Press, 2001; 171-97.

Investment Company Institute. 2000. "Defined Contribution Plan Choices at Retirement: A Survey of Employees Retiring Between 1995 and 2000," Investment Company Institute.

LIMRA International. 1997. "Product Design Series: Immediate Annuities” Annuity Research. Hartford. LIMRA International.

Menchik, P. "Economic Status as a Determinant of Mortality Among Black and White Older Men: Does Poverty Kill” Population Studies, Volume 47, Issue 3, (Nov.,1993), 427-436

Milevsky, Moshe A. 1998. "Optimal Asset Allocation Towards the End of the Life Cycle: To Annuitize or not to Annuitize?” Journal of Risk and Insurance, 65(3): 401-426.

Milevsky, Moshe. 2000. "Optimal Annuitization Policies: Analysis of the Options." North American Actuarial Journal, Vol. 5 No.1 57-69.

Milevsky, Moshe A., and Virginia R. Young. 2003 "Annuitization and Asset Allocation" Working Paper, Schulich School of Business, York University, Toronto.

Mitchell, Olivia, James Poterba, Mark J. Warshawsky and Jeffrey J. Brown. 1999. "New Evidence on the Money's Worth of Individual Annuities" American Economic Review, Vol. 89 No. 5.

Mitchell, Olivia and James F. Moore. 1997. "Retirement Wealth Accumulation and Decumulation: New Developments and Outstanding Opportunities.” NBER Working Paper No. 6178. 
Munnell, Alicia. 2003. "The Declining Role of Social Security," Center for Retirement Research Issue Brief, Boston College.

National Association for Variable Annuities. 2002. "Annuity Fact Book" 11710 Plaza America Drive, Suite 100, Reston, VA 20190.

Poterba, James M., Steven F. Venti, and David A. Wise. 2002. "Saver Behavior ad 401(k) Retirement Wealth.” American Economic Review, 90(2), pp. 297-302.

President's Commission on Social Security. December 2001. "Strengthening Social Security and Creating Personal Wealth for all Americans," http://csss.gov/reports/

Yaari, Menahem E.,1965. "Uncertain Lifetime, Life Insurance and the Theory of the Consumer" Review of Economic Studies. 32, pp.137. 


\section{Table 1a}

Composition of HRS Households' Balance Sheets at Age 65 - Couples

\begin{tabular}{|c|c|c|c|c|c|c|c|c|c|c|c|}
\hline \multicolumn{2}{|l|}{ Total Wealth Deciles } & 1 & 2 & 3 & 4 & 5 & 6 & 7 & 8 & 9 & 10 \\
\hline \multicolumn{2}{|c|}{ Lower Bound of Total Wealth } & 22,673 & 337,330 & 444,969 & 531,704 & 617,763 & 704,421 & 809,106 & 942,380 & $1,132,442$ & $1,516,948$ \\
\hline \multicolumn{12}{|c|}{ Means by Deciles } \\
\hline \multicolumn{2}{|c|}{ Net Non-Retirement Financial Wealth } & 6,670 & 14,709 & 20,485 & 42,933 & 78,267 & 88,274 & 162,910 & 218,523 & 361,731 & 853,477 \\
\hline \multicolumn{2}{|l|}{ Business Assets } & 2,368 & 3,352 & 2,239 & 9,971 & 12,267 & 12,558 & 20,607 & 27,139 & 53,718 & 206,742 \\
\hline \multicolumn{2}{|l|}{ Financial Assets } & 2,311 & 7,131 & 8,408 & 21,144 & 32,302 & 49,382 & 75,085 & 118,271 & 189,610 & 418,249 \\
\hline \multicolumn{2}{|l|}{ IRAs } & 1,991 & 4,226 & 9,838 & 11,818 & 33,698 & 26,332 & 67,218 & 73,113 & 118,403 & 228,486 \\
\hline \multicolumn{2}{|l|}{ Property } & 27,269 & 48,519 & 60,971 & 81,144 & 102,189 & 121,155 & 131,946 & 178,389 & 231,869 & 498,915 \\
\hline \multicolumn{2}{|c|}{ Primary Residence Net of Mortgage } & 26,304 & 43,887 & 52,753 & 72,607 & 82,046 & 97,797 & 101,531 & 128,033 & 157,799 & 224,929 \\
\hline \multicolumn{2}{|l|}{ Net Other Property } & 965 & 4,632 & 8,218 & 8,537 & 20,143 & 23,358 & 30,415 & 50,356 & 74,070 & 273,986 \\
\hline \multicolumn{2}{|l|}{ Retirement Wealth } & 218,257 & 327,258 & 403,626 & 451,087 & 477,526 & 546,231 & 586,141 & 640,504 & 693,709 & 897,699 \\
\hline \multicolumn{2}{|l|}{ Social Security } & 210,237 & 299,360 & 350,719 & 364,839 & 377,124 & 376,236 & 389,881 & 380,760 & 393,270 & 403,614 \\
\hline \multicolumn{2}{|l|}{ DB Pensions } & 6,635 & 21,879 & 47,242 & 78,075 & 90,553 & 155,287 & 172,895 & 235,002 & 267,588 & 364,396 \\
\hline \multicolumn{2}{|l|}{ DC Pensions } & 1,385 & 6,019 & 5,665 & 8,174 & 9,849 & 14,708 & 23,365 & 24,742 & 32,851 & 129,689 \\
\hline \multicolumn{2}{|l|}{ Total Wealth } & 252,196 & 390,486 & 485,082 & 575,164 & 657,982 & 755,660 & 880,997 & $1,037,416$ & $1,287,309$ & $2,250,092$ \\
\hline \multirow{3}{*}{$\begin{array}{c}\text { Annuitized Wealth as \% } \\
\text { of Financial and } \\
\text { Retirement Wealth }\end{array}$} & All & 96 & 93 & 94 & 91 & 86 & 85 & 78 & 75 & 66 & 53 \\
\hline & With DB & 97 & 93 & 96 & 93 & 90 & 88 & 81 & 78 & 71 & 60 \\
\hline & Without DB & 95 & 93 & 90 & 86 & 78 & 70 & 63 & 60 & 47 & 39 \\
\hline \multicolumn{2}{|l|}{ As $\%$ of Total Wealth } & 86 & 82 & 82 & 77 & 71 & 70 & 64 & 59 & 51 & 36 \\
\hline \multicolumn{2}{|l|}{$\%$ of Homeowners } & 66 & 86 & 94 & 96 & 97 & 99 & 97 & 99 & 98 & 99 \\
\hline \multicolumn{2}{|l|}{$\%$ with Living Children } & 96 & 98 & 96 & 97 & 99 & 97 & 99 & 98 & 97 & 96 \\
\hline \multirow[t]{3}{*}{$\mathrm{N}$ of obs } & Total & 154 & 153 & 154 & 153 & 153 & 154 & 153 & 154 & 153 & 138 \\
\hline & With DB & 23 & 59 & 91 & 109 & 108 & 130 & 125 & 124 & 122 & 92 \\
\hline & Without DB & 131 & 94 & 63 & 44 & 45 & 24 & 28 & 30 & 31 & 46 \\
\hline
\end{tabular}

Notes: Data from Health and Retirement Study, waves 2 to 5 . Sample: married couples who turned 65 in any of the waves 2 to 5. Sample size 1534 observations, from which 15 observations falling in the $100^{\text {th }}$ wealth percentile were dropped resulting in a sample of 1519 . We excluded the $100^{\text {th }}$ percentile from the $10^{\text {th }}$ decile and the wealth upper cut-off point is $\$ 4,294,318$. The present values of Social Security and employer Defined Benefit pensions were calculated using a real rate of interest of $3 \%$ and an inflation rate of $2.5 \%$. Annuitized wealth equals the sum of Social Security and DB pensions. All reported figures are in 1992 dollars. 


\section{Table 1b}

Composition of HRS Households' Balance Sheets at Age 65 - Single Women

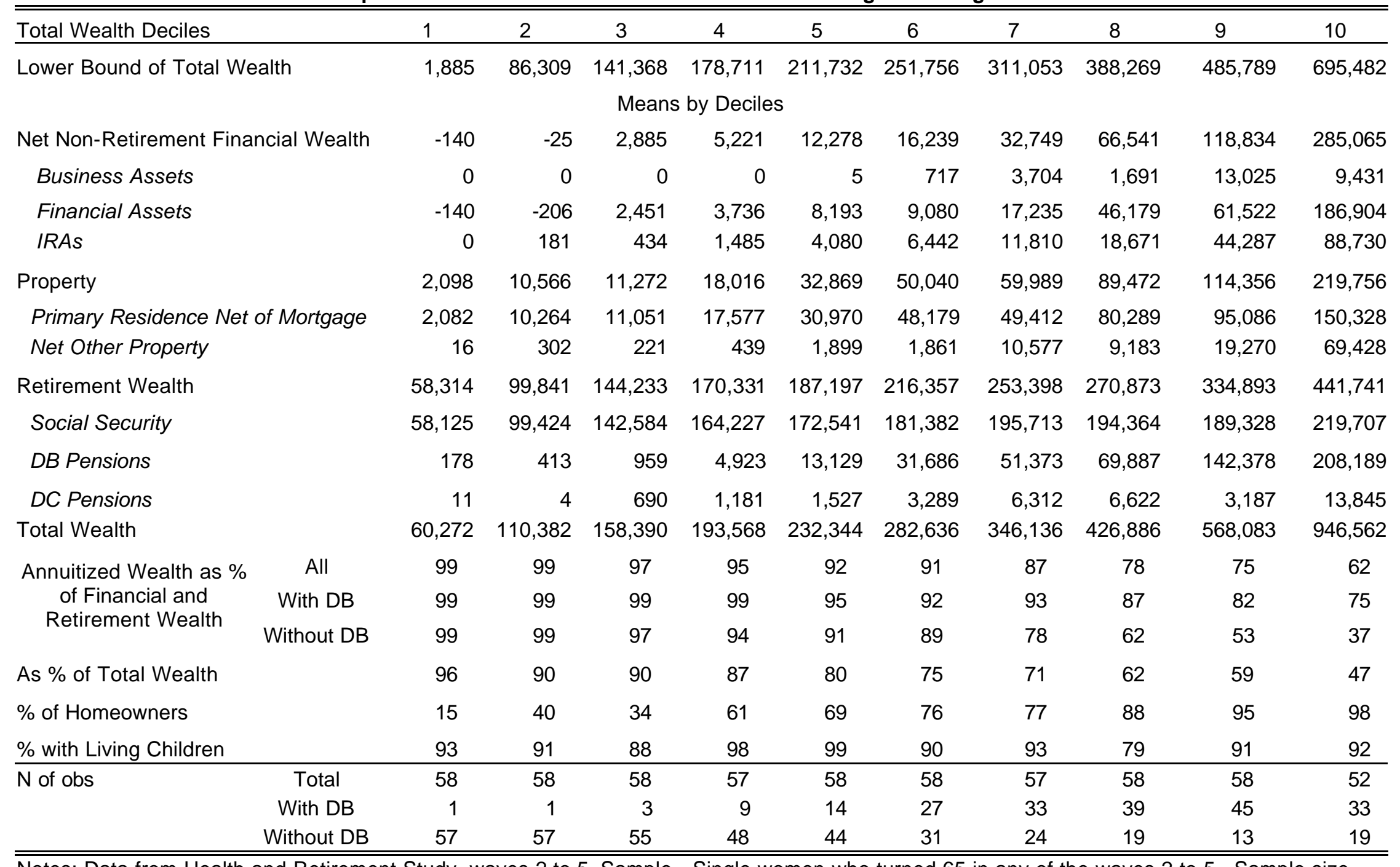

Notes: Data from Health and Retirement Study, waves 2 to 5 . Sample - Single women who turned 65 in any of the waves 2 to 5 . Sample size 577 observations, from which 5 observations falling in the $100^{\text {th }}$ wealth percentile were dropped resulting in a sample of 572 . We excluded the $100^{\text {th }}$ percentile from the $10^{\text {th }}$ decile and the wealth upper cut-off point is $\$ 1,532,258$. The present values of Social Security and employer Defined Benefit pensions were calculated using a real rate of interest of $3 \%$ and an inflation rate of $2.5 \%$. Annuitized wealth equals the sum of Social Security and DB pensions. 


\begin{tabular}{|c|c|c|c|c|c|c|c|}
\hline \multicolumn{8}{|c|}{$\begin{array}{c}\text { Table 1c } \\
\text { Composition of HRS Households' Balance Sheets at Age } 65\end{array}$} \\
\hline & & \multirow{2}{*}{ Married couples } & \multirow{2}{*}{ Single men } & \multicolumn{4}{|c|}{ Single women } \\
\hline & & & & All & Never married & $\begin{array}{l}\text { Separated/ } \\
\text { divorced }\end{array}$ & Widowed \\
\hline & & \multicolumn{6}{|c|}{ Overall Means } \\
\hline \multirow{3}{*}{\multicolumn{2}{|c|}{$\begin{array}{l}\text { Net Non-Retirement Financial Wealth } \\
\text { Business Assets } \\
\text { Financial Assets } \\
\text { IRAs }\end{array}$}} & 177,928 & 76,408 & 51,663 & 68,633 & 39,564 & 56,497 \\
\hline & & 33,338 & 25,139 & 2,792 & 353 & 853 & 4,448 \\
\hline & & $\begin{array}{l}88,844 \\
55,746\end{array}$ & $\begin{array}{l}35,559 \\
15,710\end{array}$ & $\begin{array}{l}31,967 \\
16,904\end{array}$ & $\begin{array}{l}36,234 \\
32,046\end{array}$ & $\begin{array}{l}25,087 \\
13,624\end{array}$ & $\begin{array}{l}35,635 \\
16,414\end{array}$ \\
\hline \multicolumn{2}{|l|}{ Property } & 144,639 & 67,466 & 59,253 & 39,668 & 45,050 & 71,679 \\
\hline \multirow{2}{*}{\multicolumn{2}{|c|}{$\begin{array}{l}\text { Primary Residence Net of Mortgage } \\
\text { Net Other Property }\end{array}$}} & 97,463 & 37,134 & 48,522 & 32,964 & 41,268 & 55,818 \\
\hline & & 47,176 & 30,332 & 10,731 & 6,704 & 3,782 & 15,861 \\
\hline \multicolumn{2}{|l|}{ Retirement Wealth } & 520,326 & 219,591 & 215,388 & 205,437 & 209,575 & 220,805 \\
\hline \multicolumn{2}{|l|}{ Social Security } & 354,054 & 147,407 & 161,068 & 151,294 & 149,816 & 169,931 \\
\hline \multicolumn{2}{|l|}{ DB Pensions } & 141,692 & 66,484 & 50,761 & 52,076 & 55,572 & 47,461 \\
\hline \multicolumn{2}{|l|}{ DC Pensions } & 24,580 & 5,700 & 3,559 & 2,067 & 4,187 & 3,413 \\
\hline \multicolumn{2}{|l|}{ Total Wealth } & 842,893 & 363,465 & 326,305 & 313,738 & 294,189 & 348,981 \\
\hline \multirow{3}{*}{$\begin{array}{l}\text { Annuitized Wealth as } \\
\% \text { of Financial and } \\
\text { Retirement Wealth }\end{array}$} & All & 82 & 88 & 88 & 86 & 89 & 87 \\
\hline & With DB & 83 & 85 & 87 & 85 & 90 & 85 \\
\hline & Without DB & 80 & 90 & 88 & 87 & 88 & 88 \\
\hline \multicolumn{2}{|l|}{ As $\%$ of Total Wealth } & 68 & 77 & 76 & 79 & 79 & 73 \\
\hline \multicolumn{2}{|l|}{$\%$ of Homeowners } & 93 & 55 & 65 & 52 & 61 & 70 \\
\hline \multicolumn{2}{|l|}{ \% with Living Children } & 97 & 81 & 92 & 57 & 94 & 96 \\
\hline \multirow[t]{3}{*}{$\mathrm{N}$ of obs } & Total & 1,519 & 188 & 572 & 54 & 202 & 316 \\
\hline & With DB & 983 & 67 & 205 & 21 & 67 & 117 \\
\hline & Without DB & 536 & 121 & 367 & 33 & 135 & 199 \\
\hline
\end{tabular}




\section{Table 1d}

Composition of HRS Households' Balance Sheets at Age 65 - Median 20\%

\begin{tabular}{|c|c|c|c|c|c|c|c|}
\hline & & \multirow{2}{*}{ Married couples } & \multirow{2}{*}{ Single men } & \multicolumn{4}{|c|}{ Single women } \\
\hline & & & & All & Never married & $\begin{array}{l}\text { Separated/ } \\
\text { divorced }\end{array}$ & Widowed \\
\hline \multicolumn{2}{|c|}{ Lower Bound of Total Wealth } & 617,763 & 191,593 & 211,732 & 230,386 & 214,802 & 211,732 \\
\hline \multirow{2}{*}{\multicolumn{2}{|c|}{ Upper Bound of Total Wealth }} & 808,716 & 277,286 & 310,709 & 305,524 & 310,708 & 310,324 \\
\hline & & \multicolumn{6}{|c|}{ Means of the median $20 \%$} \\
\hline \multicolumn{2}{|c|}{ Net Non-Retirement Financial Wealth } & 83,287 & 5,196 & 14,258 & 11,578 & 15,231 & 14,192 \\
\hline \multicolumn{2}{|c|}{ Business Assets } & 12,414 & 998 & 361 & 0 & 10 & 540 \\
\hline \multicolumn{2}{|l|}{ Financial Assets } & 40,870 & 1,552 & 8,637 & 6,582 & 9,157 & 8,674 \\
\hline \multicolumn{2}{|l|}{ IRAs } & 30,003 & 2,646 & 5,260 & 4,996 & 6,064 & 4,978 \\
\hline \multicolumn{2}{|l|}{ Property } & 111,703 & 23,016 & 41,455 & 41,395 & 47,867 & 38,963 \\
\hline \multicolumn{2}{|c|}{ Primary Residence Net of Mortgage } & 89,947 & 19,901 & 39,575 & 41,395 & 45,261 & 37,147 \\
\hline \multicolumn{2}{|c|}{ Net Other Property } & 21,756 & 3,115 & 1,880 & 0 & 2,606 & 1,816 \\
\hline \multicolumn{2}{|l|}{ Retirement Wealth } & 511,991 & 201,584 & 201,777 & 208,586 & 190,924 & 205,209 \\
\hline \multicolumn{2}{|l|}{ Social Security } & 376,679 & 175,795 & 176,963 & 177,554 & 164,794 & 181,633 \\
\hline \multicolumn{2}{|l|}{ DB Pensions } & 123,026 & 18,095 & 22,407 & 29,741 & 24,609 & 20,692 \\
\hline \multicolumn{2}{|l|}{ DC Pensions } & 12,286 & 7,694 & 2,408 & 1,291 & 1,521 & 2,884 \\
\hline \multicolumn{2}{|l|}{ Total Wealth } & 706,981 & 229,796 & 257,490 & 261,559 & 254,022 & 258,364 \\
\hline \multirow{3}{*}{$\begin{array}{l}\text { Annuitized Wealth as } \\
\% \text { of Financial and } \\
\text { Retirement Wealth }\end{array}$} & All & 86 & 93 & 91 & 93 & 91 & 91 \\
\hline & With DB & 89 & 94 & 93 & 98 & 93 & 92 \\
\hline & Without DB & 75 & 93 & 91 & 87 & 90 & 91 \\
\hline \multicolumn{2}{|l|}{ As $\%$ of Total Wealth } & 71 & 84 & 77 & 80 & 75 & 78 \\
\hline \multicolumn{2}{|l|}{$\%$ of Homeowners } & 98 & 42 & 72 & 67 & 77 & 71 \\
\hline \multicolumn{2}{|l|}{$\%$ with Living Children } & 98 & 84 & 95 & 78 & 100 & 95 \\
\hline \multirow[t]{3}{*}{$\mathrm{N}$ of obs } & Total & 307 & 38 & 116 & 9 & 30 & 77 \\
\hline & With DB & 238 & 12 & 41 & 5 & 9 & 27 \\
\hline & Without DB & 69 & 26 & 75 & 4 & 21 & 50 \\
\hline
\end{tabular}


Table 1e

Composition of HRS Households' Balance Sheets at Age 65, by Pension Types - Median $20 \%$

\begin{tabular}{|c|c|c|c|c|c|c|c|c|}
\hline & \multicolumn{4}{|c|}{ Married Couples } & \multicolumn{4}{|c|}{ Single Women } \\
\hline & All & With DB & DC only & $\begin{array}{c}\text { No } \\
\text { pension }\end{array}$ & All & With DB & DC only & $\begin{array}{c}\text { No } \\
\text { pension }\end{array}$ \\
\hline & \multicolumn{8}{|c|}{ Means of the Median $20 \%$} \\
\hline Net Non-Retirement Financial Wealth & 83,287 & 63,662 & 134,535 & 155,336 & 14,258 & 10,547 & 7,353 & 17,354 \\
\hline Business Assets & 12,414 & 4,727 & 31,772 & 40,759 & 361 & - & - & 625 \\
\hline Financial Assets & 40,870 & 34,416 & 48,313 & 66,906 & 8,637 & 5,729 & 4,976 & 10,853 \\
\hline IRA's & 30,003 & 24,482 & 54,449 & 47,671 & 5,260 & 4,819 & 2,377 & 5,776 \\
\hline Property & 11,703 & 95,475 & 103,835 & 183,928 & 41,455 & 25,933 & 21,602 & 53,324 \\
\hline Primary Residence Net of Mortgage & 89,947 & 81,761 & 78,314 & 128,333 & 39,575 & 25,135 & 21,602 & 50,557 \\
\hline Net Other Property & 21,756 & 13,714 & 25,521 & 55,595 & 1,880 & 798 & - & 2,766 \\
\hline Retirement Wealth & 511,991 & 553,160 & 454,350 & 348,510 & 201,777 & 233,066 & 217,621 & 180,738 \\
\hline Social Security & 376,679 & 384,513 & 354,161 & 348,510 & 176,963 & 167,278 & 194,957 & 180,738 \\
\hline DB Pensions & 123,026 & 158,693 & - & - & 22,407 & 63,397 & - & - \\
\hline DC Pensions & 12,286 & 9,955 & 100,188 & - & 2,408 & 2,391 & 22,664 & - \\
\hline Total Wealth & 706,981 & 712,257 & 692,720 & 687,774 & 257,490 & 269,546 & 246,576 & 251,416 \\
\hline $\begin{array}{l}\text { Annuitized Wealth as \% of Financial } \\
\text { and Retirement wealth }\end{array}$ & 86 & 89 & 64 & 77 & 91 & 93 & 86 & 91 \\
\hline As $\%$ of Total Wealth & 71 & 76 & 52 & 51 & 77 & 85 & 79 & 73 \\
\hline$\%$ Homeowners & 98 & 98 & 93 & 98 & 72 & 63 & 63 & 79 \\
\hline$\%$ with Living Children & 98 & 98 & 100 & 98 & 95 & 98 & 100 & 93 \\
\hline $\mathrm{N}$ of Obs. & 307 & 238 & 14 & 55 & 116 & 41 & 8 & 67 \\
\hline
\end{tabular}


Table 2a

Composition of AHEAD Households' Balance Sheets at Wave 5 - Couples

\begin{tabular}{|c|c|c|c|c|c|c|c|c|c|c|c|}
\hline \multicolumn{2}{|l|}{ Total Wealth Deciles } & 1 & 2 & 3 & 4 & 5 & 6 & 7 & 8 & 9 & 10 \\
\hline \multicolumn{2}{|c|}{ Lower Bound of Total Wealth } & $-47,767$ & 150,300 & 220,401 & 275,573 & 351,453 & 420,893 & 503,404 & 641,722 & 875,186 & $1,280,983$ \\
\hline \multicolumn{12}{|c|}{ Means by Deciles } \\
\hline \multicolumn{2}{|c|}{ Net Non-Retirement Financial Wealth } & 3,320 & 13,181 & 32,354 & 50,511 & 85,985 & 115,446 & 179,221 & 283,530 & 484,134 & $1,120,261$ \\
\hline \multicolumn{2}{|l|}{ Business Assets } & 392 & 297 & 50 & 1,040 & 1,188 & 7,553 & 7,014 & 23,436 & 60,703 & 152,825 \\
\hline \multicolumn{2}{|l|}{ Financial Assets } & 2,389 & 11,518 & 30,113 & 43,241 & 67,684 & 89,548 & 140,168 & 229,555 & 326,618 & 811,429 \\
\hline \multicolumn{2}{|l|}{ IRAs } & 539 & 1,366 & 2,191 & 6,230 & 17,113 & 18,345 & 32,039 & 30,539 & 96,813 & 156,007 \\
\hline \multicolumn{2}{|l|}{ Property } & 25,469 & 53,906 & 63,713 & 96,292 & 102,154 & 126,875 & 151,836 & 212,067 & 270,012 & 549,242 \\
\hline \multicolumn{2}{|c|}{ Primary Residence Net of Mortgage } & 24,625 & 52,713 & 56,050 & 85,886 & 91,445 & 110,375 & 125,158 & 137,925 & 179,474 & 277,044 \\
\hline \multicolumn{2}{|l|}{ Net Other Property } & 844 & 1,193 & 7,663 & 10,406 & 10,709 & 16,500 & 26,678 & 74,142 & 90,538 & 272,198 \\
\hline \multicolumn{2}{|l|}{ Retirement Wealth } & 71,566 & 117,069 & 150,560 & 166,955 & 191,896 & 214,802 & 234,690 & 255,889 & 308,055 & 422,228 \\
\hline \multicolumn{2}{|l|}{ Social Security } & 64,241 & 101,345 & 113,722 & 121,000 & 125,994 & 131,001 & 129,458 & 139,335 & 140,364 & 148,555 \\
\hline \multicolumn{2}{|l|}{ DB Pensions } & 7,325 & 15,724 & 36,838 & 45,695 & 65,902 & 83,801 & 105,232 & 116,554 & 167,691 & 273,673 \\
\hline \multicolumn{2}{|l|}{ DC Pensions } & - & - & - & - & - & - & - & - & - & - \\
\hline \multicolumn{2}{|l|}{ Total Wealth } & 100,355 & 184,156 & 246,627 & 313,498 & 380,035 & 457,123 & 565,747 & 751,486 & $1,062,201$ & $2,091,731$ \\
\hline \multirow{3}{*}{$\begin{array}{l}\text { Annuitized Wealth as } \\
\% \text { of Financial and } \\
\text { Retirement Wealth }\end{array}$} & Total & 93 & 88 & 81 & 77 & 70 & 68 & 58 & 51 & 45 & 34 \\
\hline & With DB & 94 & 90 & 83 & 80 & 75 & 72 & 61 & 58 & 50 & 39 \\
\hline & Without DB & 92 & 87 & 78 & 71 & 49 & 50 & 43 & 36 & 27 & 21 \\
\hline \multicolumn{2}{|l|}{ As $\%$ of Total Wealth } & 70 & 64 & 61 & 53 & 50 & 47 & 41 & 34 & 29 & 21 \\
\hline \multicolumn{2}{|l|}{$\%$ of Homeowners } & 72 & 88 & 88 & 94 & 92 & 96 & 96 & 92 & 99 & 100 \\
\hline \multicolumn{2}{|l|}{ Age } & 83 & 81 & 81 & 81 & 80 & 80 & 80 & 80 & 80 & 80 \\
\hline \multirow[t]{3}{*}{$\mathrm{N}$ of obs } & Total & 102 & 101 & 101 & 101 & 101 & 102 & 101 & 101 & 101 & 91 \\
\hline & With DB & 37 & 51 & 66 & 70 & 80 & 82 & 86 & 71 & 77 & 67 \\
\hline & Without DB & 65 & 50 & 35 & 31 & 21 & 20 & 15 & 30 & 24 & 24 \\
\hline
\end{tabular}

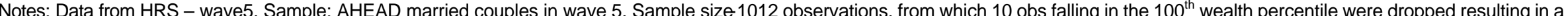
sample of 1002 . We excluded the $100^{\text {th }}$ percentile from the $10^{\text {th }}$ decile and the wealth upper cut-off point is $\$ 5,528,553$. The present values of SS and employer DB pensions were calculated

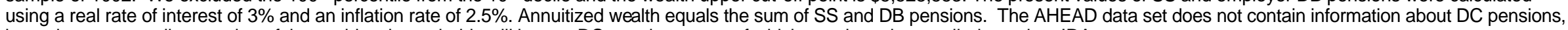
but only a very small proportion of these oldest households will have a DC pension, some of which may have been rolled over into IRAs. 


\section{Table 2b}

Composition of AHEAD Households' Balance Sheets at Wave 5 - Single women

\begin{tabular}{|c|c|c|c|c|c|c|c|c|c|c|c|}
\hline \multicolumn{2}{|l|}{ Total Wealth Deciles } & 1 & 2 & 3 & 4 & 5 & 6 & 7 & 8 & 9 & 10 \\
\hline \multicolumn{2}{|l|}{ Lower Bound of Total Wealth } & $-1,826$ & 47,986 & 68,699 & 95,506 & 126,789 & 156,744 & 196,858 & 255,131 & 349,858 & 557,321 \\
\hline \multicolumn{12}{|c|}{ Means by Deciles } \\
\hline \multicolumn{2}{|c|}{ Net Non-Retirement Financial Wealth } & 78 & 1,557 & 5,523 & 7,812 & 13,549 & 26,145 & 37,604 & 74,457 & 152,267 & 465,906 \\
\hline \multicolumn{2}{|l|}{ Business Assets } & 0 & 0 & 63 & 0 & 253 & 1,202 & 2,627 & 1,835 & 9,494 & 35,070 \\
\hline \multicolumn{2}{|l|}{ Financial Assets } & 78 & 1,551 & 5,340 & 7,543 & 13,071 & 23,776 & 32,814 & 65,781 & 132,803 & 404,017 \\
\hline \multicolumn{2}{|l|}{ IRAs } & 0 & 6 & 120 & 269 & 225 & 1,167 & 2,163 & 6,841 & 9,970 & 26,819 \\
\hline \multicolumn{2}{|l|}{ Property } & 2,167 & 6,889 & 19,697 & 37,137 & 51,678 & 67,114 & 92,552 & 112,628 & 164,105 & 254,045 \\
\hline \multicolumn{2}{|c|}{ Primary Residence Net of Mortgage } & 2,164 & 6,668 & 18,890 & 36,086 & 50,653 & 65,560 & 85,922 & 101,479 & 130,485 & 179,189 \\
\hline \multicolumn{2}{|l|}{ Net Other Property } & 3 & 221 & 807 & 1,051 & 1,025 & 1,554 & 6,630 & 11,149 & 33,620 & 74,856 \\
\hline \multicolumn{2}{|l|}{ Retirement Wealth } & 32,008 & 49,081 & 56,303 & 64,615 & 76,428 & 82,220 & 94,090 & 107,776 & 125,333 & 174,478 \\
\hline \multicolumn{2}{|l|}{ Social Security } & 31,353 & 47,190 & 51,059 & 54,859 & 57,965 & 60,218 & 68,194 & 70,858 & 72,057 & 71,983 \\
\hline \multicolumn{2}{|l|}{ DB Pensions } & 655 & 1,891 & 5,244 & 9,756 & 18,463 & 22,002 & 25,896 & 36,918 & 53,276 & 102,495 \\
\hline \multicolumn{2}{|l|}{ DC Pensions } & - & - & - & - & - & - & - & - & - & - \\
\hline \multicolumn{2}{|l|}{ Total Wealth } & 34,253 & 57,527 & 81,523 & 109,564 & 141,655 & 175,479 & 224,246 & 294,861 & 441,705 & 894,429 \\
\hline \multirow{3}{*}{$\begin{array}{c}\text { Annuitized Wealth as \% of } \\
\text { Financial and Retirement } \\
\text { Wealth }\end{array}$} & All & 94 & 96 & 90 & 90 & 86 & 80 & 77 & 64 & 54 & 36 \\
\hline & With DB & 97 & 98 & 90 & 91 & 90 & 83 & 80 & 72 & 59 & 40 \\
\hline & Without DB & 93 & 96 & 90 & 89 & 82 & 76 & 74 & 53 & 45 & 25 \\
\hline \multirow{2}{*}{\multicolumn{2}{|c|}{$\begin{array}{l}\text { As \% of Total Wealth } \\
\% \text { of Homeowners }\end{array}$}} & 89 & 85 & 69 & 59 & 54 & 47 & 42 & 37 & 28 & 21 \\
\hline & & 18 & 33 & 58 & 72 & 83 & 84 & 91 & 89 & 90 & 88 \\
\hline \multicolumn{2}{|l|}{ Age } & 87 & 83 & 83 & 83 & 82 & 82 & 82 & 81 & 81 & 82 \\
\hline \multirow[t]{3}{*}{$\mathrm{N}$ of obs } & All & 158 & 158 & 158 & 158 & 158 & 158 & 158 & 158 & 158 & 142 \\
\hline & With DB & 15 & 23 & 41 & 55 & 78 & 79 & 80 & 93 & 105 & 101 \\
\hline & Without DB & 143 & 135 & 117 & 103 & 80 & 79 & 78 & 65 & 53 & 41 \\
\hline
\end{tabular}


Table 2c

Composition of AHEAD Households' Balance Sheets at Wave 5

\begin{tabular}{|c|c|c|c|c|c|c|c|}
\hline & & \multirow{2}{*}{$\begin{array}{l}\text { Married } \\
\text { Couples }\end{array}$} & \multirow[b]{2}{*}{ Single men } & \multicolumn{4}{|c|}{ Single women } \\
\hline & & & & All & Never married & $\begin{array}{l}\text { Separated/ } \\
\text { divorced }\end{array}$ & Widowed \\
\hline & & \multicolumn{6}{|c|}{ Overall Means } \\
\hline \multicolumn{2}{|c|}{ Net Non-Retirement Financial Wealth } & 227,623 & 134,820 & 74,526 & 83,590 & 57,122 & 75,991 \\
\hline \multicolumn{2}{|c|}{ Business Assets } & 24,136 & 8,667 & 4,747 & 2,112 & 5,467 & 4,806 \\
\hline \multirow{2}{*}{\multicolumn{2}{|c|}{$\begin{array}{l}\text { Financial Assets } \\
\text { IRAs }\end{array}$}} & 168,619 & 115,228 & 65,247 & 75,037 & 47,858 & 66,671 \\
\hline & & 34,868 & 10,925 & 4,532 & 6,441 & 3,797 & 4,514 \\
\hline \multicolumn{2}{|l|}{ Property } & 161,146 & 95,933 & 79,029 & 58,796 & 58,223 & 82,423 \\
\hline \multicolumn{2}{|c|}{ Primary Residence Net of Mortgage } & 112,350 & 68,281 & 66,569 & 55,704 & 51,123 & 68,869 \\
\hline \multicolumn{2}{|c|}{ Net Other Property } & 48,796 & 27,653 & 12,460 & 3,092 & 7,100 & 13,554 \\
\hline \multicolumn{2}{|l|}{ Retirement Wealth } & 211,120 & 104,727 & 85,331 & 100,120 & 77,980 & 85,369 \\
\hline \multicolumn{2}{|l|}{ Social Security } & 121,184 & 58,371 & 58,437 & 57,323 & 55,247 & 58,856 \\
\hline \multicolumn{2}{|l|}{ DB Pensions } & 89,936 & 46,356 & 26,894 & 42,887 & 22,733 & 26,513 \\
\hline \multicolumn{2}{|l|}{ DC Pensions } & - & - & - & - & - & - \\
\hline \multicolumn{2}{|l|}{ Total Wealth } & 599,889 & 335,480 & 238,886 & 242,506 & 193,325 & 243,783 \\
\hline \multirow{3}{*}{$\begin{array}{l}\text { Annuitized Wealth as } \\
\% \text { of Financial and } \\
\text { Retirement Wealth }\end{array}$} & All & 67 & 70 & 77 & 75 & 82 & 77 \\
\hline & With DB & 68 & 68 & 74 & 69 & 79 & 73 \\
\hline & Without DB & 64 & 72 & 80 & 80 & 84 & 79 \\
\hline \multirow{2}{*}{\multicolumn{2}{|c|}{$\begin{array}{l}\text { As \% of Total wealth } \\
\% \text { homeowners }\end{array}$}} & 47 & 51 & 53 & 57 & 60 & 53 \\
\hline & & 92 & 68 & 70 & 55 & 62 & 72 \\
\hline \multicolumn{2}{|l|}{ Age } & 81 & 82 & 83 & 83 & 81 & 83 \\
\hline \multirow[t]{3}{*}{$\mathrm{N}$ of obs } & Total & 1,002 & 474 & 1,564 & 71 & 150 & 1,343 \\
\hline & With DB & 687 & 293 & 670 & 31 & 59 & 580 \\
\hline & Without DB & 315 & 181 & 894 & 40 & 91 & 763 \\
\hline
\end{tabular}




\begin{tabular}{|c|c|c|c|c|c|c|c|}
\hline \multicolumn{7}{|c|}{$\begin{array}{c}\text { Table 2d } \\
\text { omposition of AHEAD Households' Balance Sr }\end{array}$} & \\
\hline \multicolumn{7}{|c|}{ omposition of AHEAD Households' Balance SH } & \\
\hline & & & Single men & All & Never married & $\begin{array}{l}\text { omen } \\
\text { Separated/ } \\
\text { divorced }\end{array}$ & Widowed \\
\hline \multicolumn{2}{|c|}{ Lower Bound of Total Wealth } & 351,453 & 153,436 & 126,789 & 132,038 & 128,992 & 126,789 \\
\hline \multirow{2}{*}{\multicolumn{2}{|c|}{ Upper Bound of Total Wealth }} & 502,179 & 255,563 & 196,783 & 183,368 & 196,783 & 196,559 \\
\hline & & \multicolumn{6}{|c|}{ Means of the median $20 \%$} \\
\hline \multicolumn{2}{|c|}{ Net Non-Retirement Financial Wealth } & 100,788 & 36,911 & 19,847 & 19,521 & 23,253 & 19,447 \\
\hline \multicolumn{2}{|l|}{ Business Assets } & 4,386 & 1,316 & 728 & 0 & 1,212 & 691 \\
\hline \multicolumn{2}{|l|}{ Financial Assets } & 78,670 & 33,122 & 18,423 & 17,521 & 21,041 & 18,135 \\
\hline \multicolumn{2}{|l|}{ IRAs } & 17,732 & 2,473 & 696 & 2,000 & 1,000 & 621 \\
\hline \multicolumn{2}{|l|}{ Property } & 114,576 & 62,646 & 59,396 & 75,500 & 53,379 & 59,737 \\
\hline \multicolumn{2}{|c|}{ Primary Residence Net of Mortgage } & 100,957 & 60,010 & 58,106 & 72,500 & 52,394 & 58,373 \\
\hline \multicolumn{2}{|l|}{ Net Other Property } & 13,619 & 2,636 & 1,290 & 0 & 985 & 1,364 \\
\hline \multicolumn{2}{|l|}{ Retirement Wealth } & 203,406 & 103,487 & 79,324 & 73,187 & 85,369 & 78,778 \\
\hline \multicolumn{2}{|l|}{ Social Security } & 128,510 & 66,191 & 59,092 & 52,904 & 60,417 & 59,113 \\
\hline \multicolumn{2}{|l|}{ DB Pensions } & 74,896 & 37,296 & 20,232 & 20,283 & 24,952 & 19,665 \\
\hline \multicolumn{2}{|l|}{ DC Pensions } & - & - & - & - & - & \\
\hline \multicolumn{2}{|l|}{ Total Wealth } & 418,770 & 203,044 & 158,567 & 165,208 & 162,001 & 157,962 \\
\hline \multirow{3}{*}{$\begin{array}{l}\text { Annuitized Wealth as } \\
\% \text { of Financial and } \\
\text { Retirement Wealth }\end{array}$} & All & 69 & 75 & 83 & 82 & 84 & 83 \\
\hline & With DB & 74 & 78 & 86 & 80 & 85 & 86 \\
\hline & Without DB & 50 & 66 & 79 & 84 & 82 & 79 \\
\hline \multicolumn{2}{|l|}{ As $\%$ of Total Wealth } & 49 & 52 & 50 & 46 & 54 & 50 \\
\hline \multicolumn{2}{|l|}{$\%$ of homeowners } & 94 & 80 & 84 & 63 & 79 & 85 \\
\hline \multicolumn{2}{|l|}{ Age } & 80 & 81 & 82 & 83 & 80 & 83 \\
\hline \multirow[t]{3}{*}{$\mathrm{N}$ of obs } & Total & 203 & 95 & 316 & 8 & 33 & 275 \\
\hline & With DB & 162 & 72 & 157 & 4 & 17 & 136 \\
\hline & Without DB & 41 & 23 & 159 & 4 & 16 & 139 \\
\hline
\end{tabular}


Table 2e

Composition of AHEAD Households' Balance Sheets at Wave 5, by Pension Types - Median 20\%

\begin{tabular}{|c|c|c|c|c|c|c|}
\hline & \multicolumn{3}{|c|}{ Married Couples } & \multicolumn{3}{|c|}{ Single women } \\
\hline & All & With DB & Without DB & All & With DB & Without DB \\
\hline & \multicolumn{6}{|c|}{ Means of the median $20 \%$} \\
\hline Net Non-Retirement Financial Wealth & 100,788 & 85,190 & 162,419 & 19,847 & 17,872 & 21,798 \\
\hline Business Assets & 4,386 & 1,790 & 14,644 & 728 & 255 & 1,195 \\
\hline Financial Assets & 78,670 & 69,221 & 116,007 & 18,423 & 17,151 & 19,680 \\
\hline IRA's & 17,732 & 14,179 & 31,768 & 696 & 466 & 923 \\
\hline Property & 114,576 & 111,081 & 128,385 & 59,396 & 44,270 & 74,331 \\
\hline Primary Residence Net of Mortgage & 100,957 & 102,336 & 95,507 & 58,106 & 43,334 & 72,693 \\
\hline Net Other Property & 13,619 & 8,744 & 32,878 & 1,290 & 936 & 1,638 \\
\hline Retirement Wealth & 203,406 & 223,508 & 123,975 & 79,324 & 98,118 & 60,767 \\
\hline Social Security & 128,510 & 129,658 & 123,975 & 59,092 & 57,395 & 60,767 \\
\hline DB Pensions & 74,896 & 93,851 & - & 20,232 & 40,723 & - \\
\hline DC Pensions & - & - & - & - & - & - \\
\hline Total Wealth & 418,770 & 419,779 & 414,779 & 158,567 & 160,259 & 156,897 \\
\hline $\begin{array}{l}\text { Annuitized Wealth as \% of Financial and } \\
\text { Retirement Wealth }\end{array}$ & 69 & 74 & 50 & 83 & 86 & 79 \\
\hline As $\%$ of Total Wealth & 49 & 54 & 30 & 50 & 61 & 39 \\
\hline$\%$ of homeowners & 94 & 96 & 85 & 84 & 75 & 92 \\
\hline Age & 80 & 80 & 81 & 82 & 82 & 83 \\
\hline $\mathrm{N}$ of obs & 203 & 162 & 41 & 316 & 157 & 159 \\
\hline
\end{tabular}


Table 3a

Optimal ages at which to start and complete the process of annuitizing one's wealth using population mortality tables

\begin{tabular}{|c|c|c|c|c|c|}
\hline & & \multicolumn{4}{|c|}{ Expected present value } \\
\hline & & \multicolumn{2}{|c|}{$85.60 \%$} & \multicolumn{2}{|c|}{$79.20 \%$} \\
\hline & & $\begin{array}{c}\text { Optimal age to } \\
\text { start annuitization }\end{array}$ & $\begin{array}{l}\% \text { of initial wealth } \\
\text { remaining prior to } \\
\text { annuitization }\end{array}$ & $\begin{array}{c}\text { Optimal age to } \\
\text { start } \\
\text { annuitization }\end{array}$ & $\begin{array}{l}\% \text { of initial wealth } \\
\text { remaining prior to } \\
\text { annuitization }\end{array}$ \\
\hline & & \multicolumn{4}{|c|}{ No pre-annuitized wealth } \\
\hline \multirow[t]{3}{*}{ Risk aversion = 1} & Couple & 83 & 30 & 89 & 13 \\
\hline & Single male & 65 & 100 & 65 & 100 \\
\hline & Single female & 65 & 100 & 70 & 83 \\
\hline \multirow[t]{3}{*}{ Risk aversion $=2$} & Couple & 77 & 59 & 83 & 38 \\
\hline & Single male & 65 & 100 & 65 & 100 \\
\hline & Single female & 65 & 100 & 71 & 83 \\
\hline \multirow[t]{4}{*}{ Risk aversion $=5$} & Couple & 70 & 85 & 74 & 74 \\
\hline & Single male & 65 & 100 & 65 & 100 \\
\hline & Single female & 65 & 100 & 70 & 88 \\
\hline & & \multicolumn{4}{|c|}{$50 \%$ wealth pre-annuitized } \\
\hline \multirow[t]{3}{*}{ Risk aversion $=1$} & Couple & Never & 0 & Never & 0 \\
\hline & Single male & 65 & 100 & 65 & 100 \\
\hline & Single female & 65 & 100 & 70 & 77 \\
\hline \multirow[t]{3}{*}{ Risk aversion $=2$} & Couple & Never & 0 & Never & 0 \\
\hline & Single male & 65 & 100 & 65 & 100 \\
\hline & Single female & 66 & 96 & 69 & 87 \\
\hline \multirow[t]{4}{*}{ Risk aversion $=5$} & Couple & 73 & 73 & 82 & 44 \\
\hline & Single male & 65 & 100 & 65 & 100 \\
\hline & Single female & 65 & 100 & 70 & 87 \\
\hline & & \multicolumn{4}{|c|}{$75 \%$ wealth pre-annuitized } \\
\hline \multirow[t]{3}{*}{ Risk aversion = 1} & Couple & Never & 0 & Never & 0 \\
\hline & Single male & 65 & 100 & 65 & 100 \\
\hline & Single female & 66 & 94 & Never & 0 \\
\hline \multirow[t]{3}{*}{ Risk aversion = 2} & Couple & Never & 0 & Never & 0 \\
\hline & Single male & 65 & 100 & 65 & 100 \\
\hline & Single female & 65 & 100 & 70 & 78 \\
\hline \multirow[t]{3}{*}{ Risk aversion $=5$} & Couple & Never & 0 & Never & 0 \\
\hline & Single male & 65 & 100 & 65 & 100 \\
\hline & Single female & 65 & 100 & 71 & 82 \\
\hline
\end{tabular}

$?=0.5, ?=0.9709, p=0.025, r=0.03$, wife three years younger than husband, mortality $=$ SSA table for 1930 male and 1933 female birth cohorts, 2/3 annuity survivor benefit. 


\section{Table 3b}

\section{Optimal ages at which to start and complete the process of annuitizing one's wealth}

using annuitant mortality tables

\begin{tabular}{|c|c|c|c|c|c|}
\hline & & \multicolumn{4}{|c|}{ Expected present value } \\
\hline & & \multicolumn{2}{|c|}{$92.40 \%$} & \multicolumn{2}{|c|}{$84.90 \%$} \\
\hline & & $\begin{array}{l}\text { Optimal age to } \\
\text { start annuitization }\end{array}$ & $\begin{array}{c}\% \text { of initial wealth } \\
\text { remaining prior to } \\
\text { annuitization }\end{array}$ & $\begin{array}{c}\text { Optimal age to } \\
\text { start } \\
\text { annuitization }\end{array}$ & $\begin{array}{l}\% \text { of initial wealth } \\
\text { remaining prior to } \\
\text { annuitization }\end{array}$ \\
\hline & & \multicolumn{4}{|c|}{ No pre-annuitized wealth } \\
\hline \multirow[t]{3}{*}{ Risk aversion = 1} & Couple & 76 & 61 & 87 & 24 \\
\hline & Single male & 65 & 100 & 65 & 100 \\
\hline & Single female & 65 & 100 & 65 & 100 \\
\hline \multirow[t]{3}{*}{ Risk aversion $=2$} & Couple & 72 & 79 & 80 & 54 \\
\hline & Single male & 65 & 100 & 65 & 100 \\
\hline & Single female & 65 & 100 & 65 & 100 \\
\hline \multirow[t]{4}{*}{ Risk aversion $=5$} & Couple & 65 & 100 & 73 & 79 \\
\hline & Single male & 65 & 100 & 65 & 100 \\
\hline & Single female & 65 & 100 & 65 & 100 \\
\hline & & \multicolumn{4}{|c|}{$50 \%$ wealth pre-annuitized } \\
\hline \multirow[t]{3}{*}{ Risk aversion = 1} & Couple & Never & - & Never & - \\
\hline & Single male & 65 & 100 & 65 & 100 \\
\hline & Single female & 65 & 100 & 65 & 100 \\
\hline \multirow[t]{3}{*}{ Risk aversion $=2$} & Couple & 77 & 58 & Never & - \\
\hline & Single male & 65 & 100 & 65 & 100 \\
\hline & Single female & 65 & 100 & 74 & 70 \\
\hline \multirow[t]{4}{*}{ Risk aversion $=5$} & Couple & 69 & 89 & 80 & 61 \\
\hline & Single male & 65 & 100 & 65 & 100 \\
\hline & Single female & 65 & 100 & 65 & 100 \\
\hline & & \multicolumn{4}{|c|}{$75 \%$ wealth pre-annuitized } \\
\hline \multirow[t]{3}{*}{ Risk aversion = 1} & Couple & Never & - & Never & - \\
\hline & Single male & 65 & 100 & 65 & 100 \\
\hline & Single female & 65 & 100 & Never & - \\
\hline \multirow[t]{3}{*}{ Risk aversion $=2$} & Couple & Never & - & Never & - \\
\hline & Single male & 65 & 100 & 65 & 100 \\
\hline & Single female & 65 & 100 & 65 & 100 \\
\hline \multirow[t]{3}{*}{ Risk aversion $=5$} & Couple & 80 & 18 & Never & - \\
\hline & Single male & 65 & 100 & 65 & 100 \\
\hline & Single female & 65 & 100 & 65 & 100 \\
\hline
\end{tabular}

$?=0.5, ?=0.9709, p=0.025, r=0.03$, wife three years younger than husband, mortality $=$ annuitant, $2 / 3$ survivor benefit. 


\begin{tabular}{|c|c|c|c|c|c|c|c|}
\hline \multicolumn{8}{|c|}{$\begin{array}{c}\text { Table } 4 \\
\text { Optimal Age at Which to Annuitize - population mortality tables }\end{array}$} \\
\hline & & \multicolumn{4}{|c|}{ HRS } & \multicolumn{2}{|c|}{ AHEAD } \\
\hline & & $\begin{array}{c}\text { No } \\
\text { Pension }\end{array}$ & $\begin{array}{l}\mathrm{DB} \text { or } \\
\mathrm{DB} \text { and } \\
\mathrm{DC}\end{array}$ & DC only & $\begin{array}{l}\text { DB } \\
\text { replaced } \\
\text { by DC }\end{array}$ & $\begin{array}{l}\text { No } \\
\text { Pension }\end{array}$ & DB \\
\hline \multicolumn{8}{|c|}{ Married couples } \\
\hline \multicolumn{2}{|c|}{$\%$ pre-annuitized 1} & 94 & 86 & 75 & 58 & 50 & 84 \\
\hline \multirow[t]{3}{*}{ EPDV $85.6 \%$} & $\mathrm{CRRA}=1$ & Never & Never & Never & Never & Never & Never \\
\hline & 2 & Never & Never & Never & Never & 82 & Never \\
\hline & 5 & Never & Never & Never & 78 & 81 & 81 \\
\hline \multirow[t]{3}{*}{ EPDV $79.2 \%$} & $\mathrm{CRRA}=1$ & Never & Never & Never & Never & Never & Never \\
\hline & 2 & Never & Never & Never & Never & Never & Never \\
\hline & 5 & Never & Never & Never & Never & Never & Never \\
\hline \multicolumn{8}{|c|}{ Single women ${ }^{2}$} \\
\hline \multicolumn{2}{|c|}{$\%$ pre-annuitized } & 96 & 87 & 75 & 62 & 80 & 84 \\
\hline \multirow[t]{3}{*}{ EPDV $85.6 \%$} & $\mathrm{CRRA}=1$ & Never & Never & 65 & 65 & 81 & 81 \\
\hline & 2 & Never & 65 & 65 & 65 & 81 & 81 \\
\hline & 5 & Never & 65 & 65 & 65 & 81 & 81 \\
\hline \multirow[t]{3}{*}{ EPDV $79.2 \%$} & $\mathrm{CRRA}=1$ & Never & Never & Never & 68 & Never & Never \\
\hline & 2 & Never & Never & 68 & 67 & 81 & 81 \\
\hline & 5 & Never & 68 & 67 & 69 & 81 & 81 \\
\hline
\end{tabular}


Figure I.

Optimal Consumption

CRRA $=1$, EPDV $=0.792,50 \%$ Pre-annuitized wealth
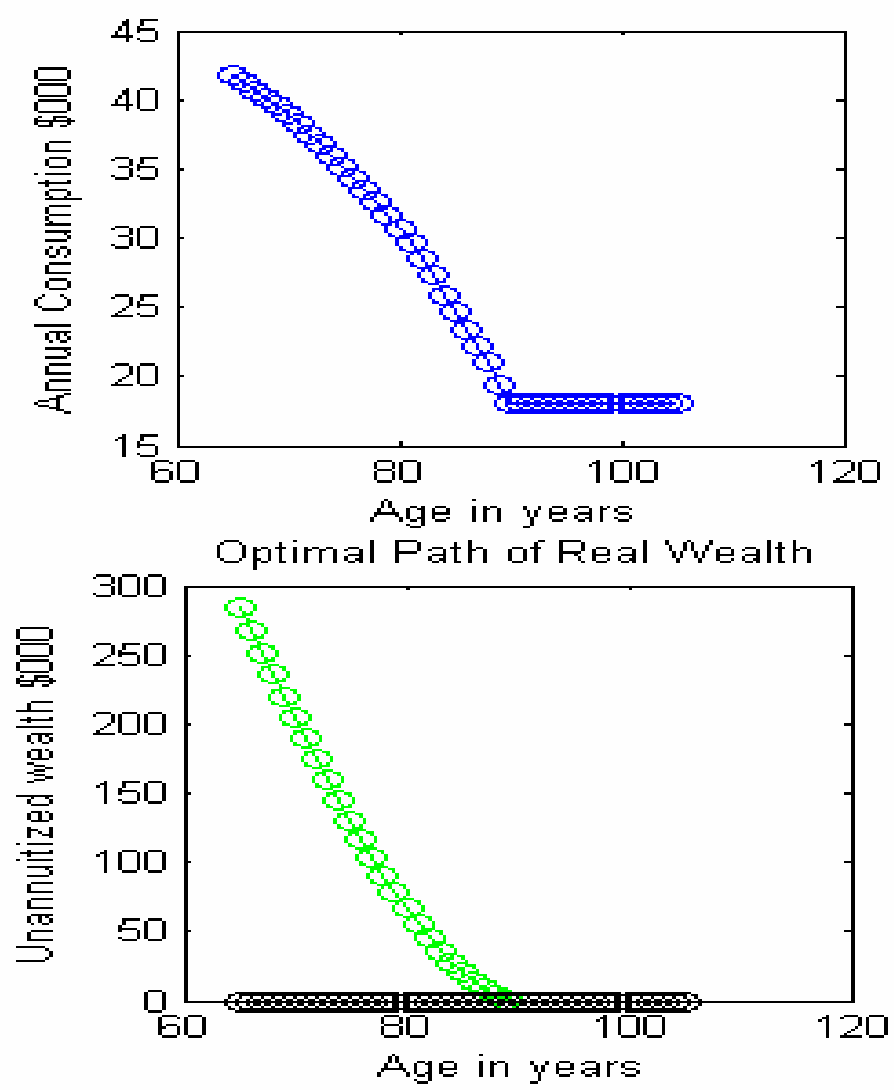


\section{Figure II}
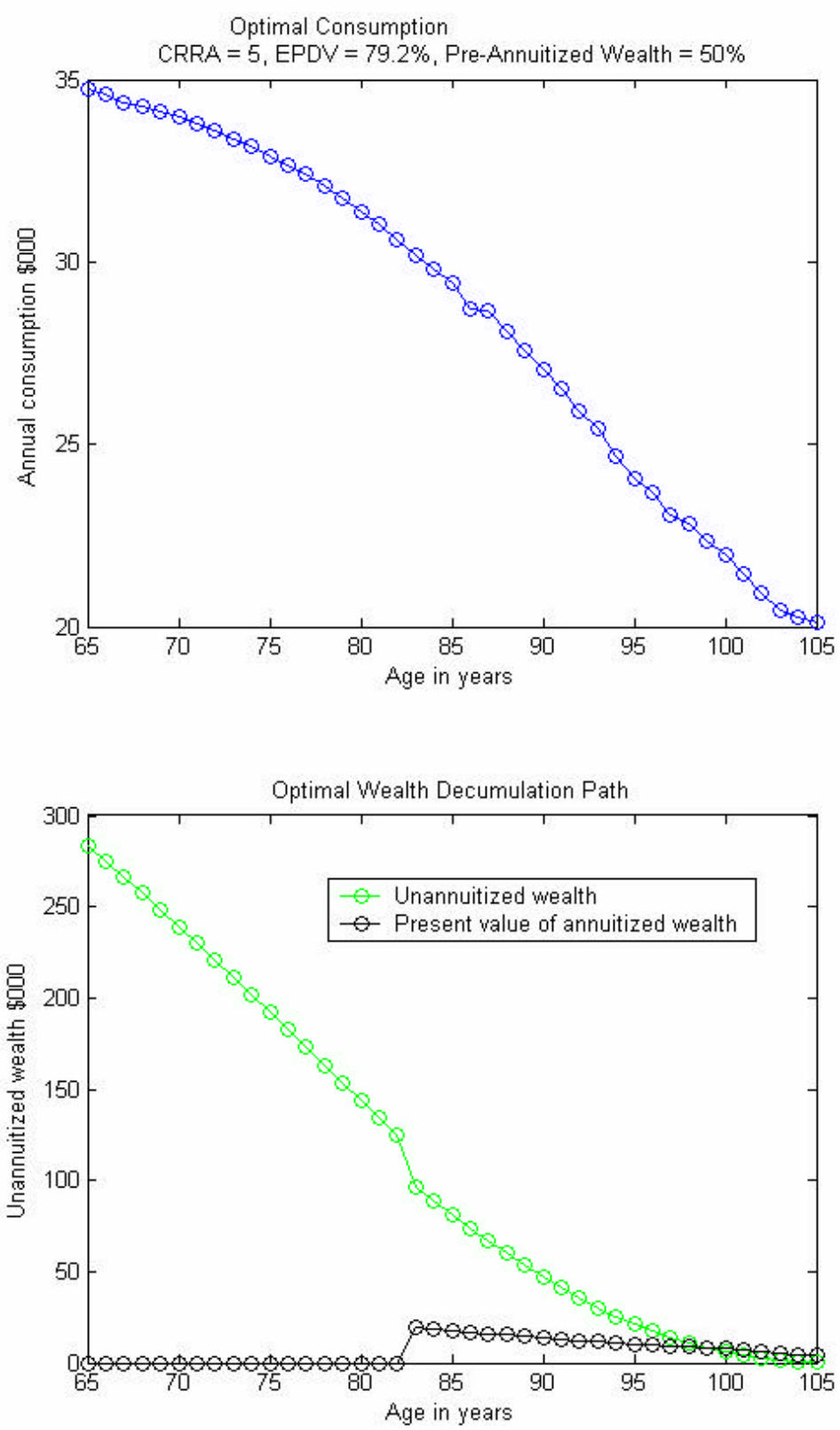


\section{RECENT WORKING PAPERS FROM THE \\ Center For Retirement Research at Boston College}

Living Arrangements and Supplemental Security Income Receipt Among the Aged Melissa M. Favreault and Douglas A. Wolf, February 2004

Interactions Between Social Security Reform and the Supplemental Security Income Program for the Aged

Paul S. Davies and Melissa M. Favreault, February 2004

Supply-Side Consequences of Social Security Reform: Impacts on Saving and Employment

Barry Bosworth and Gary Burtless, January 2004

It's All Relative: Understanding the Retirement Prospects of Baby-Boomers

Barbara A. Butrica, Howard M. Iams, and Karen E. Smith, November 2003

The Notional Defined Contribution Model: An Assessment of the Strengths and Limitations of a New Approach to the Provision of Old Age Security

John B. Williamson and Matthew Williams, October 2003

Simulating the Distributional Consequences of Personal Accounts: Sensitivity to Annuitization Options

Cori E. Uccello, Melissa M. Favreault, Karen E. Smith, and Lawrence H. Thompson, October 2003

Aggregate Implications of Defined Benefit and Defined Contribution Systems Francisco Gomes and Alexander Michaelides, September 2003

Can Unexpected Retirement Explain the Retirement-Consumption Puzzle? Evidence for Subjective Retirement Explanations Melvin Stephens Jr. and Steven J. Haider, August 2003

Employment, Social Security and Future Retirement Outcomes for Single Mothers Richard W. Johnson, Melissa M. Favreault, and Joshua H. Goldwyn, July 2003

The Outlook for Pension Contributions and Profits in the U.S. Alicia H. Munnell and Mauricio Soto, June 2003

Social Security Reform and the Exchange of Bequests for Elder Care Meta Brown, June 2003

All working papers are available on the Center for Retirement Research website (http://www.bc.edu/crr) and can be requested by e-mail (crr@bc.edu) or phone (617-552-1762). 